\title{
31. MIOCENE-AGE PRIMARY PRODUCTIVITY EPISODES AND OXYGEN MINIMA IN THE CENTRAL EQUATORIAL INDIAN OCEAN ${ }^{1}$
}

\author{
Anne Boersma ${ }^{2}$ and Naja Mikkelsen ${ }^{3}$
}

\begin{abstract}
Combined data on benthic foraminifers, siliceous fossils, and stable isotopes depict times of enhanced organic carbon oxidation in the sediments and high primary productivity in the southern Indian upwelling zone during the Miocene. Increased abundance of the diatom productivity index, the Thalassionema group, elevated diatom and uvigerinid abundances, and bolivinid diversity all suggest heightened primary productivity and the development of a mid-depth oxygen minimum between $\sim 17$ and $10 \mathrm{Ma}$.

The abundance of bolivinids with large pores and crenulate chamber surfaces may indicate more aerated pore waters in the upper few centimeters of the partly siliceous sediments deposited during the episode of higher primary productivity and increased organic carbon flux around $10 \mathrm{Ma}$.
\end{abstract}

\section{INTRODUCTION}

Leg 115 to the north central Indian Ocean drilled Site 714 into grey to dark grey-green, mildly to strongly reduced Neogene-age sediments on the northeast portion of the Chagos-Laccadive Ridge (Fig. 1). Because the site is located near $2038 \mathrm{mbsl}$ within the upwelling zone offshore southern India, it is ideally suited to monitor primary production and oxygen reduction episodes in the upwelling zone. The sediments, characterized by light-dark color cycles, contained abundant diatoms and unusually high abundances of the benthic foraminifer genus Bolivina. Because bolivinids are known to characterize oxygen minima (Douglas and Heitman, 1979; Poag and Low, 1984), a special study of Miocene-age bolivinids was combined with quantitative analysis of diatom floras and stable isotope measurements of benthic and planktonic foraminifers to trace conditions in and under the upwelling zone throughout the Miocene.

\section{METHODS}

Benthic faunas from Site 714 have been previously described (Backman, Duncan, et al., 1988), and detailed range charts are reported in Boersma (this volume). I disaggregated $20-\mathrm{cm}^{3}$ samples through a $63-\mu \mathrm{m}$ sieve and air dried them; I then recorded the benthic foraminifers from $1 \mathrm{mg}$ of each sample according to the following scheme: $1=$ one specimen present, $2=2-3$ specimens, $3=3-5,4=5-10,5=10-15,6=15-20,7=20-30,8$ $=30-50$, and $9=50-100$. Counting done in this way provides an estimate of benthic and species abundance in a standardized sample size; hence, it approximates benthic accumulation rates.

Several benthic foraminifer indexes were estimated. These included species diversity (species richness) and the numbers of infaunal and epifaunal species. Corliss and Chen (1988), after differentiating living infaunal from epifaunal benthic foraminifers in the Norwegian Sea, found a direct relation between higher numbers of infaunal species and an elevated flux of organic carbon to the bottom higher and organic carbon contents of the

\footnotetext{
${ }^{1}$ Duncan, R. A., Backman, J., Peterson, L. C., et al., 1990. Proc. ODP, Sci. Results, 115: College Station, TX (Ocean Drilling Program).

2540 Gate Hill Road, Stony Point, NY 10980, U.S.A.

${ }^{3}$ Geological Survey of Denmark, Thoravej 8, DK2400, Copenhagen, Denmark.
}

sediments. In contrast, increased numbers of epifauna were related to more aerated conditions at the bottom and lower organic carbon contents in the sediments.

Several rectilinear genera were not classified by Corliss and Chen (1988). Because all their other rectilinear forms were infaunal, however, calcareous rectilinear species in this study were counted as infauna. This involved primarily the stilostomellids.

Bolivinids were studied in detail from the total $>63-\mu \mathrm{m}$ size fraction. Throughout most of the section, bolivinids predominated in the $>63-<125-\mu \mathrm{m}$ size fractions. Following detailed picking, pore size was estimated by means of the light microscope and was then confirmed by scanning microscope pictures provided by I. Premoli Silva, University of Milan.

Diatom samples were processed during the cruise in groups of 10-15 samples per batch. Approximately 2-3 gm of each sample was placed in a $250-\mathrm{ml}$ beaker and $25-\mathrm{ml}$ of $10 \%$ hydrochloric acid was added. The sample was gently heated until the liquid became light yellow. Treatment with $30 \%$ hydrogen peroxide was rarely required. The liquid was decanted after $11 / 2 \mathrm{hr}$, allowing a settling rate of at least $1 \mathrm{~cm} / 10 \mathrm{~min}$. The decanting process was repeated three times. Strewn slides were prepared by transferring the suspended material to a cover slip that was then dried and mounted with Hyrax on glass slides. Additional samples were prepared after the cruise. To save time, only a small amount of sample $(0.1 \mathrm{~g})$ was placed in a $50-\mathrm{ml}$ glass tube and subjected to the settling method described above.

A biostratigraphic zonation for Site 714 , made by D. Rio and H. Okada and reported in Backman, Duncan, et al. (1988), is shown in Figure 2. Although nannofossil biozones are used here, the equivalent planktonic foraminifer biozone will often be indicated in the text.

Carbon and oxygen isotopes were measured in species of the benthic foraminifer genera Cibicidoides, Planulina, Rectuvigerina, Cassidulina, Uvigerina, and Globocassidulina from the $>250-\mu \mathrm{m}$ size fraction by N. J. Shackleton and M. Hall at Cambridge University (Table 1). The rotaloid genera are considered to precipitate the carbon isotopes in their carbonate close to equilibrium with the carbon in $\mathrm{HCO}_{3}$ of surrounding seawater (Woodruff and Savin, 1989). Uvigerina and Globocassidulina precipitate the carbonate in their tests close to equilibrium with oxygen in seawater (Shackleton et al., 1984). Shackleton and Hall also measured 5-20 specimens of the planktonic foraminifer species Globigerinoides sacculifer from the $>250-\mu \mathrm{m}$ size fraction. 


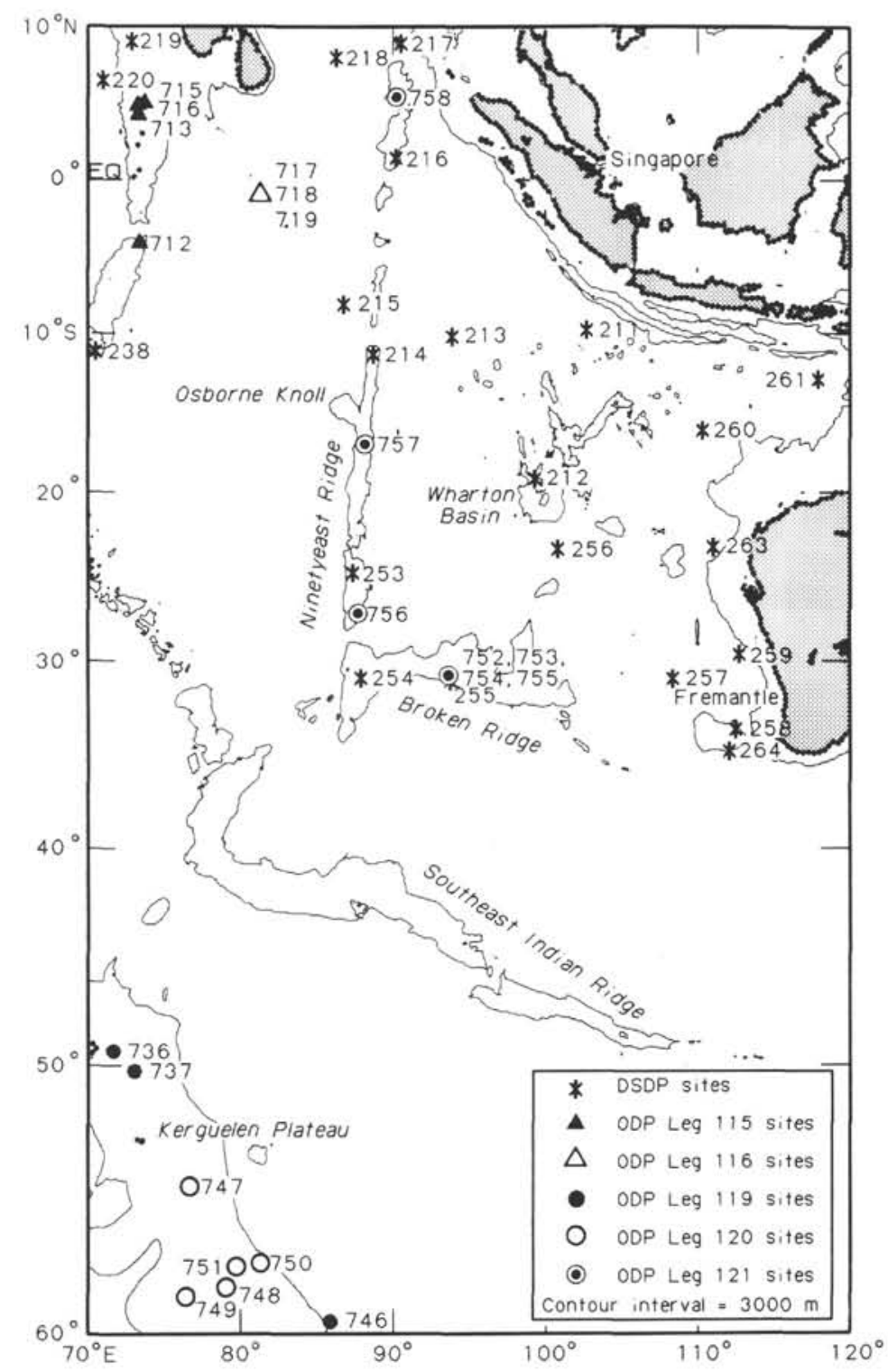

Figure 1. Location map of the eastern Indian Ocean showing DSDP and ODP sites.

\section{BOLIVINID STUDIES}

Because sedimentary layering varied from dark green to tannish grey in color, becoming darkest near the top of the section, episodic variations in reducing potential in the sediment were proposed (Backman, Duncan, et al., 1988). To determine if faunas reflected these color variations, a sample pair was chosen from darker, more reduced vs. lighter, less reduced laminae in Core 115-714B-8H. Faunal components compared quantitatively between the more and less reduced levels are shown in Figure 3. The upper, lighter colored lamina at Sample 115-714B-8H-4, 8 $\mathrm{cm}$, contained six bolivinid species, including elevated abundances of the finely porous Bolivina pukeuriensis, the coarsely punctate forms Bolivina pseudoplicata and Bolivina peregrina, and a delicate, small-pored, elongate form of Bolivina goessi. The accompanying planktonic foraminifer faunas were rich in globorotaliids and neogloboquadrinids, with few Globigerinoides ruber. Siliceous fossils, especially spicules and some diatoms, were abundant in this sample.

Figure 3 confirms that differently colored laminae may contain different benthic and planktonic foraminifer faunas. The darker colored lamina from Sample 115-714B-8H-4, $30 \mathrm{~cm}$, contained eight bolivinid species, but a high dominance of three types, the crenulate forms B. pseudoplicata and Bolivina hebes, Bolivina pulchra, and a delicate, elongate form of $B$. goessi with small- to medium-sized pores. Uvigerinids were significantly more abundant in this sample (Fig. 3). Warm-water planktonic foraminifer species such as $G$. ruber were common, whereas keeled globorotaliids were infrequent. Only a few siliceous fossils were present.

\section{Bolivinid Morphology and Sediment Chemistry}

Recognition of low-oxygen conditions may be possible using bolivinid test type. Phleger and Soutar (1973) showed that in low-oxygen environments bolivinids tend to have thin walls and small pores, and that a few species are highly dominant. Douglas (1981) determined that chamber shape and cross-sectional shape were directly related to oxygenation at the bottom in the California borderland basins. The lower the oxygen values, the smoother the bolivinid, the larger its size, and the flatter its test. He reasoned that a larger surface-to-volume ratio would be an advantage for respiration under low-oxygen conditions. 


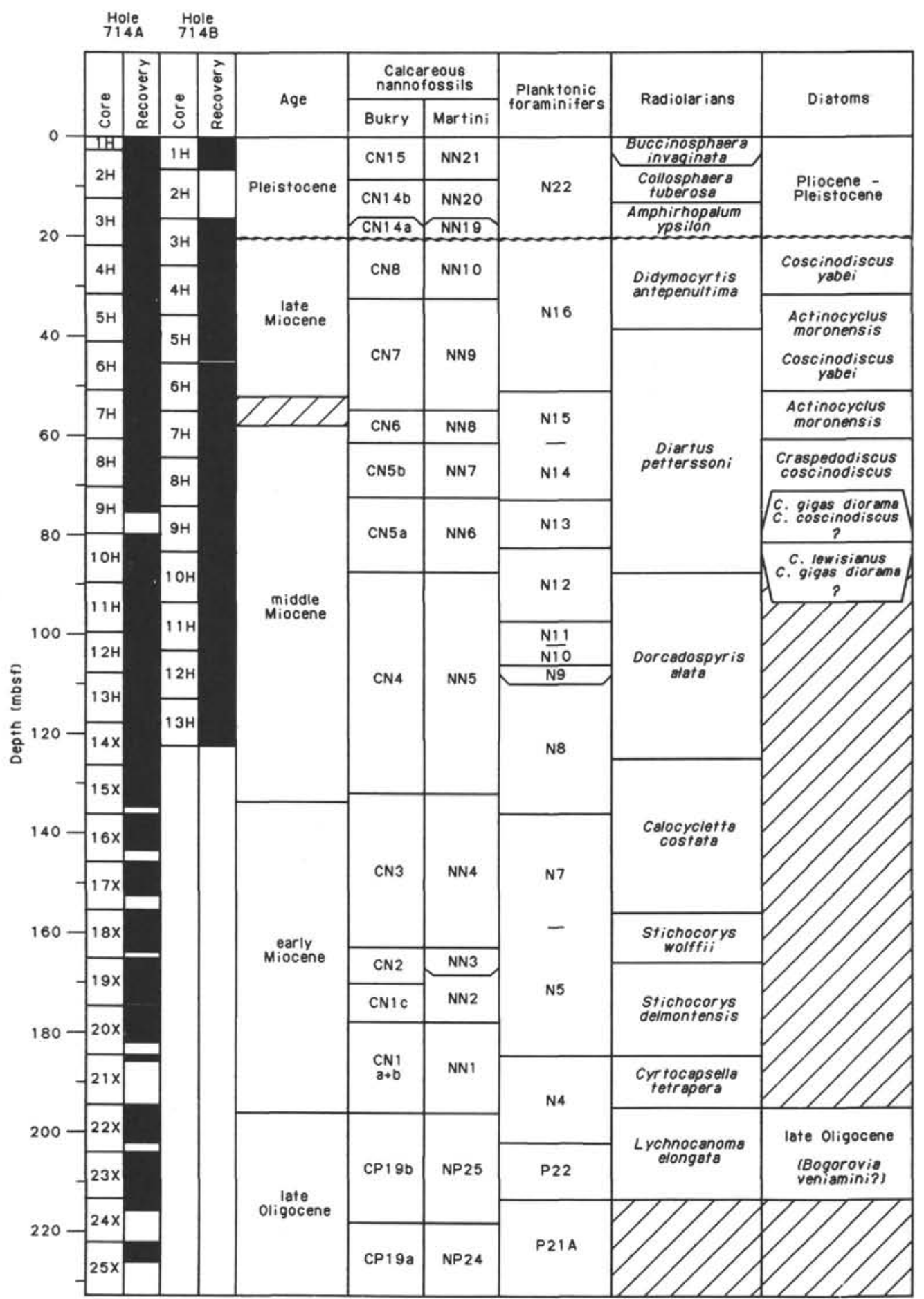

Figure 2. Biostratigraphic zonation of Site 714 from Backman, Duncan, et al., 1988.

In a study of benthic foraminifer ornamentation and sedimentary components in the Los Angeles and Ventura basins, Hendrix (1958) reached a seemingly different conclusion. Sharpedged, moderately costate or keeled variants predominated in massive sediments, whereas smooth-edged or unkeeled ecophenotypes with more rounded test margins were more abundant in laminated sediments. Both clay and organic carbon content were greater in the laminated intervals. The larger the contrast of clay and organic carbon content between the massive and laminated levels, the greater was the difference in foraminifer ornamentation. He also found a direct relation between clay and organic carbon content and benthic foraminifer abundance. Although
Hendrix (1958) did not relate test ornament to oxygenation, the elevated organic carbon values in laminated sediments today are related to the presence of an oxygen minimum and exclusion of infaunal predators (Phleger and Soutar, 1973; Douglas and Heitman, 1979; Douglas, 1981).

Together with test shape, inflation, and ornamentation, foraminifer pore size changes in oxygen-rich environments. Like planktonic foraminifers, bolivinids have pores that penetrate the test wall ending in pore plates. Mitochondria congregate at these pore plates during reproduction and are involved in respiration and gas exchange (Leutenegger and Hansen, 1979). Apparently, when pores are small, protoplasm remains within the test, 
Table 1. Stable isotope ratios in planktonic and benthic foraminifer species from the Miocene in Hole $714 B$.

\begin{tabular}{|c|c|c|c|}
\hline $\begin{array}{l}\text { Depth } \\
\text { (mbsf) }\end{array}$ & Species & ${ }^{18} \mathrm{O}$ & ${ }^{13} \mathrm{C}$ \\
\hline \multirow[t]{3}{*}{26.5} & Globocassidulina subglobosa & 2.83 & -0.03 \\
\hline & Cibicides wuellerstorfi & 2.08 & 0.92 \\
\hline & Globigerinoides sacculifer & -2.01 & 1.89 \\
\hline \multirow[t]{2}{*}{27.2} & C. wuellerstorfi & 2.42 & 0.71 \\
\hline & G. sacculifer & -2.00 & 1.97 \\
\hline \multirow[t]{3}{*}{28.0} & G. subglobosa & 2.94 & -0.18 \\
\hline & C. wuellerstorfi & 2.33 & 0.51 \\
\hline & G. sacculifer & -2.09 & 2.07 \\
\hline \multirow[t]{3}{*}{28.7} & G. subglobosa & 2.77 & -0.21 \\
\hline & C. wuellerstorfi & 2.16 & 0.67 \\
\hline & G. sacculifer & -2.36 & 2.47 \\
\hline \multirow[t]{3}{*}{29.5} & Uvigerina spp. & 2.54 & -0.26 \\
\hline & C. wuellerstorfi & 2.23 & 0.65 \\
\hline & G. sacculifer & -1.87 & 1.75 \\
\hline \multirow[t]{3}{*}{30.2} & Uvigerina spp. & 2.78 & 0.10 \\
\hline & C. wuellerstorfi & 2.48 & 0.54 \\
\hline & G. sacculifer & -1.99 & 2.00 \\
\hline \multirow[t]{3}{*}{31.0} & G. subglobosa & 2.79 & 0.10 \\
\hline & C. wuellerstorfi & 2.11 & 0.60 \\
\hline & G. sacculifer & -2.23 & 2.40 \\
\hline \multirow[t]{3}{*}{31.7} & G. subglobosa & 2.99 & -0.09 \\
\hline & C. wuellerstorfi & 2.30 & 0.61 \\
\hline & G. sacculifer & -2.02 & 2.05 \\
\hline \multirow[t]{3}{*}{33.0} & G. subglobosa & 2.96 & 0.10 \\
\hline & C. wuellerstorfi & 2.35 & 0.42 \\
\hline & G. sacculifer & -1.65 & 1.75 \\
\hline 33.2 & Uvigerina spp. & 2.85 & -0.36 \\
\hline & G. subglobosa & 2.95 & 0.14 \\
\hline & C. wuellerstorfi & 2.35 & 0.44 \\
\hline & G. sacculifer & -1.89 & 1.86 \\
\hline 36.7 & Uvigerina spp. & 2.66 & -0.10 \\
\hline & G. subglobosa & 2.81 & 0.06 \\
\hline & C. wuellerstorfi & 2.16 & 0.74 \\
\hline & G. sacculifer & -2.04 & 2.08 \\
\hline 36.9 & G. subglobosa & 2.66 & 0.14 \\
\hline & C. wuellerstorfi & 2.20 & 0.72 \\
\hline 37.7 & G. subglobosa & 2.75 & 0.05 \\
\hline 38.4 & Planulina renzi & 2.09 & 0.51 \\
\hline & G. sacculifer & -2.11 & 2.11 \\
\hline 39.2 & G. subglobosa & 2.76 & 0.16 \\
\hline & C. wuellerstorfi & 2.12 & 0.87 \\
\hline & G. sacculifer & -2.47 & 2.26 \\
\hline 39.7 & Rectuvigerina spinea & 2.75 & -0.41 \\
\hline & C. wuellerstorfi & 2.29 & 0.60 \\
\hline 39.9 & G. subglobosa & 2.90 & -0.05 \\
\hline & C. wuellerstorfi & 2.31 & 0.65 \\
\hline & G. sacculifer & -1.83 & 1.93 \\
\hline 40.7 & Uvigerina spp. & 2.85 & -0.17 \\
\hline & C. wuellerstorfi & 2.20 & 0.55 \\
\hline & G. sacculifer & -2.07 & 2.16 \\
\hline 41.2 & C. wuellerstorfi & 1.90 & 0.39 \\
\hline 41.3 & G. sacculifer & -2.04 & 1.99 \\
\hline 41.4 & C. wuellerstorfi & 2.09 & 0.55 \\
\hline & G. sacculifer & -2.24 & 2.05 \\
\hline 42.2 & R. spinea & 2.49 & -0.42 \\
\hline & Cibicidoides spp. & 1.93 & 0.27 \\
\hline & G. sacculifer & -2.26 & 1.64 \\
\hline 42.9 & G. subglobosa & 2.55 & -0.03 \\
\hline & G. sacculifer & -1.62 & 1.98 \\
\hline 43.5 & G. sacculifer & -1.94 & 1.99 \\
\hline 43.7 & R. spinea & 2.48 & -0.31 \\
\hline 44.2 & G. sacculifer & -2.04 & 1.90 \\
\hline 44.4 & C. wuellerstorfi & 2.27 & 0.91 \\
\hline 45.9 & G. subglobosa & 2.82 & 0.04 \\
\hline & C. wuellerstorfi & 2.29 & 0.73 \\
\hline & G. sacculifer & -2.24 & 2.11 \\
\hline 46.6 & C. wuellerstorfi & 2.59 & -0.02 \\
\hline & $P$ renzi & 2.00 & 0.48 \\
\hline & G. sacculifer & -1.60 & 1.61 \\
\hline 47.4 & R. spinea & 2.58 & -0.15 \\
\hline & C. wuellerstorfi & 2.03 & 0.73 \\
\hline & P. renzi & 1.86 & 0.59 \\
\hline & G. sacculifer & -2.18 & 1.79 \\
\hline 48.1 & C. wuellerstorfi & 2.07 & 0.74 \\
\hline & G. sacculifer & -2.19 & 1.82 \\
\hline
\end{tabular}

Table 1 (continued).

\begin{tabular}{|c|c|c|c|}
\hline $\begin{array}{l}\text { Depth } \\
\text { (mbsf) }\end{array}$ & Species & ${ }^{18} \mathrm{O}$ & ${ }^{13} \mathrm{C}$ \\
\hline \multirow[t]{3}{*}{49.6} & G. subglobosa & 2.71 & 0.25 \\
\hline & C. wuellerstorfi & 2.01 & 0.90 \\
\hline & G. sacculifer & -2.03 & 2.22 \\
\hline \multirow[t]{3}{*}{50.4} & G. subglobosa & 2.73 & 0.31 \\
\hline & C. wuellerstorfi & 2.14 & 0.89 \\
\hline & G. sacculifer & -1.50 & 2.19 \\
\hline \multirow[t]{2}{*}{51.1} & C. wuellerstorfi & 2.16 & 0.95 \\
\hline & G. sacculifer & -1.34 & 1.75 \\
\hline \multirow[t]{3}{*}{51.9} & G. subglobosa & 2.68 & 0.31 \\
\hline & C. wuellerstorfi & 1.91 & 0.89 \\
\hline & G. sacculifer & -2.03 & 1.83 \\
\hline \multirow[t]{3}{*}{52.6} & G. subglobosa & 2.75 & 0.05 \\
\hline & C. wuellerstorfi & 2.03 & 0.67 \\
\hline & G. sacculifer & -2.10 & 1.82 \\
\hline \multirow[t]{2}{*}{53.4} & C. wuellerstorfi & 1.85 & 0.70 \\
\hline & G. sacculifer & -2.07 & 1.65 \\
\hline \multirow[t]{2}{*}{54.1} & P. renzi & 1.77 & 0.78 \\
\hline & G. sacculifer & -2.53 & 1.99 \\
\hline \multirow[t]{2}{*}{54.9} & C. wuellerstorfi & 1.99 & 0.66 \\
\hline & G. sacculifer & -2.13 & 2.13 \\
\hline 56.2 & C. wuellerstorfi & 2.11 & 0.80 \\
\hline & P. renzi & 2.07 & 0.64 \\
\hline & G. sacculifer & -1.61 & 1.54 \\
\hline 57.7 & G. subglobosa & 2.57 & 0.09 \\
\hline & G. subglobosa & 2.71 & 0.29 \\
\hline & C. wuellerstorfi & 1.88 & 0.68 \\
\hline & C. wuellerstorfi & 1.31 & 0.40 \\
\hline & C. wuellerstorfi & 2.13 & 0.68 \\
\hline & P. renzi & 2.06 & 0.64 \\
\hline 60.7 & G. subglobosa & 2.89 & 0.34 \\
\hline & C. wuellerstorfi & 2.13 & 0.77 \\
\hline & G. sacculifer & -1.83 & 1.74 \\
\hline 61.5 & Uvigerina spp. & 2.75 & -0.02 \\
\hline & G. subglobosa & 2.80 & 0.07 \\
\hline & P. renzi & 2.00 & 0.60 \\
\hline & G. sacculifer & -2.36 & 1.89 \\
\hline 63.0 & G. subglobosa & 2.72 & 0.30 \\
\hline & C. wuellerstorfi & 2.18 & 1.05 \\
\hline & G. sacculifer & -1.97 & 2.04 \\
\hline 64.5 & G. subglobosa & 2.49 & 0.53 \\
\hline & C. wuellerstorfi & 2.02 & 1.18 \\
\hline & G. sacculifer & -1.68 & 2.57 \\
\hline 65.1 & G. sacculifer & -2.48 & 2.26 \\
\hline 65.4 & G. subglobosa & 2.60 & 0.35 \\
\hline & C. wuellerstorfi & 2.04 & 1.11 \\
\hline 67.3 & C. wuellerstorfi & 2.16 & 1.14 \\
\hline & G. sacculifer & -1.48 & 2.02 \\
\hline 68.1 & G. subglobosa & 2.55 & 0.71 \\
\hline & C. wuellerstorfi & 2.10 & 1.25 \\
\hline & P. renzi & 1.79 & 1.14 \\
\hline & G. sacculifer & -2.01 & 2.29 \\
\hline 69.1 & G. subglobosa & 2.71 & 0.29 \\
\hline & C. wuellerstorfi & 1.96 & 0.87 \\
\hline & P. renzi & 1.72 & 0.86 \\
\hline & Cassidulinoides cornuta & 2.81 & 0.39 \\
\hline & G. sacculifer & -1.65 & 1.91 \\
\hline 69.4 & $R$. spinea & 2.41 & -0.27 \\
\hline & G. subglobosa & 2.60 & -0.07 \\
\hline & C. wuellerstorfi & 1.99 & 0.90 \\
\hline & $P$ renzi & 1.85 & 0.84 \\
\hline & G. sacculifer & -1.77 & 2.11 \\
\hline 70.3 & G. subglobosa & 2.57 & 0.19 \\
\hline & C. wuellerstorfi & 1.93 & 0.75 \\
\hline & G. sacculifer & -2.02 & 1.89 \\
\hline 71.8 & P. renzi & 1.82 & 0.81 \\
\hline & P. renzi & 1.96 & 1.03 \\
\hline 75.5 & P. renzi & 2.04 & 0.96 \\
\hline 77.0 & P. renzi & 1.95 & 1.12 \\
\hline 78.5 & P. renzi & 1.77 & 0.84 \\
\hline 81.5 & G. subglobosa & 2.80 & 0.35 \\
\hline & C. wuellerstorfi & 2.09 & 0.91 \\
\hline 89.6 & C. wuellerstorfi & 1.65 & 1.78 \\
\hline 105 & G. subglobosa & 1.96 & 1.28 \\
\hline 119 & P. renzi & 1.70 & 1.34 \\
\hline 120 & C. wuellerstorfi & 1.05 & 1.71 \\
\hline 184 & G. subglobosa & 2.29 & 0.53 \\
\hline & P. renzi & 1.23 & 0.86 \\
\hline
\end{tabular}


Table 1 (continued).

\begin{tabular}{llll}
\hline $\begin{array}{l}\text { Depth } \\
\text { (mbsf) }\end{array}$ & \multicolumn{1}{c}{ Species } & ${ }^{18} \mathrm{O}$ & ${ }^{13} \mathrm{C}$ \\
\hline 194 & P. renzi & 1.54 & 1.22 \\
195 & P. renzi & 1.01 & 0.91 \\
197 & G. subglobosa & 1.93 & 0.79 \\
& P. renzi & 1.17 & 1.27 \\
200 & P. renzi & 1.05 & 0.73 \\
205 & G. subglobosa & 2.00 & 0.54 \\
& P. renzi & 1.14 & 0.87 \\
& & &
\end{tabular}

Note: Data provided by N. Shackleton and M. Hall, Cambridge University. Fossils were measured from the $>250-\mu \mathrm{m}$ size fraction.

whereas protoplasm and mitochondria may extend outside the test through large-sized pores. Pore size and test porosity are related to environment; larger pores and greater test porosity occur both in warmer and in more oxygenated waters. Smaller, micropores characterize waters with lower oxygen concentrations (Bé et al., 1973; Hemleben et al., 1989.)

Thus, consideration of pore size, and hence porosity, will complement analyses based on test shape and ornament. Smooth, almost poreless species occurred in the laminated, organic carbon-rich levels of Hendrix's (1958) study. The large, flat, smooth species such as Bolivina argentea, indicative of lower oxygen levels in the California borderland basins, also have smaller pores, although the smaller species with a rhomboidal cross-section, such as Bolivina vaughani, have larger pores.

Neogene-age bolivinids at Site 714 can be subdivided into five groups on the basis of their morphological features. The tests of Group 1 species are typically flattened to lenticular in cross-section, larger in size than those of the accompanying bolivinids. They are lanceolate in shape, with arched sutures often demonstrating small hooks near the central axis of the test, and have small pores randomly distributed over the chambers. The surface is usually unornamented but may display a reticular pattern. Typical species of this group include Bolivina miocenica, Bolivina retiformis, and $B$. goessi.

The tests of Group 2 species (Plate 1) are typically flattened to lenticular in cross-section, small in size, and prolate in shape. They contain many chambers, with straight, internally limbate sutures producing a sort of fish-skeleton internal pattern; and they have medium-sized pores randomly distributed over the chambers. The surface is usually ornamented with a few or many costulae, which traverse nearly three-quarters of the chambers along the test length. Typical species of this group include Bolivina tectiformis, Bolivina pusilla, and an elongate form of $B$. goessi that may be a separate species.

The tests of Group 3 species (Plate 2 ) are typically lenticular in cross-section, small to medium in size, and shaped with roughly subparallel sides. They have few chambers that overlap in the central portion of the test to produce a sort of woven appearance and straight sutures; small- to medium-sized pores are randomly distributed over the chambers. The surface may or may not be ornamented with longitudinal costulae or costae, which traverse nearly three-quarters of the test. Typical species of this group include Bolivina arta, Bolivina striatocola, Bolivina pseudogemma, Bolivina optima, and a multichambered form Bolivina dilatata.

The tests of Group 4 species (Plate 3 ) are characterized by a subrhomboid to suboval cross-section, small size, and narrow, rounded, triangular shape. They have few chambers, large pores often surrounded by ridges, and few to numerous crenulations of the chambers, some of which align into longitudinal folds running the length of the test. Typical species of this group include $B$. hebes, $B$. pseudoplicata, and probably $B$. peregrina.

\section{Species Hole 714B}

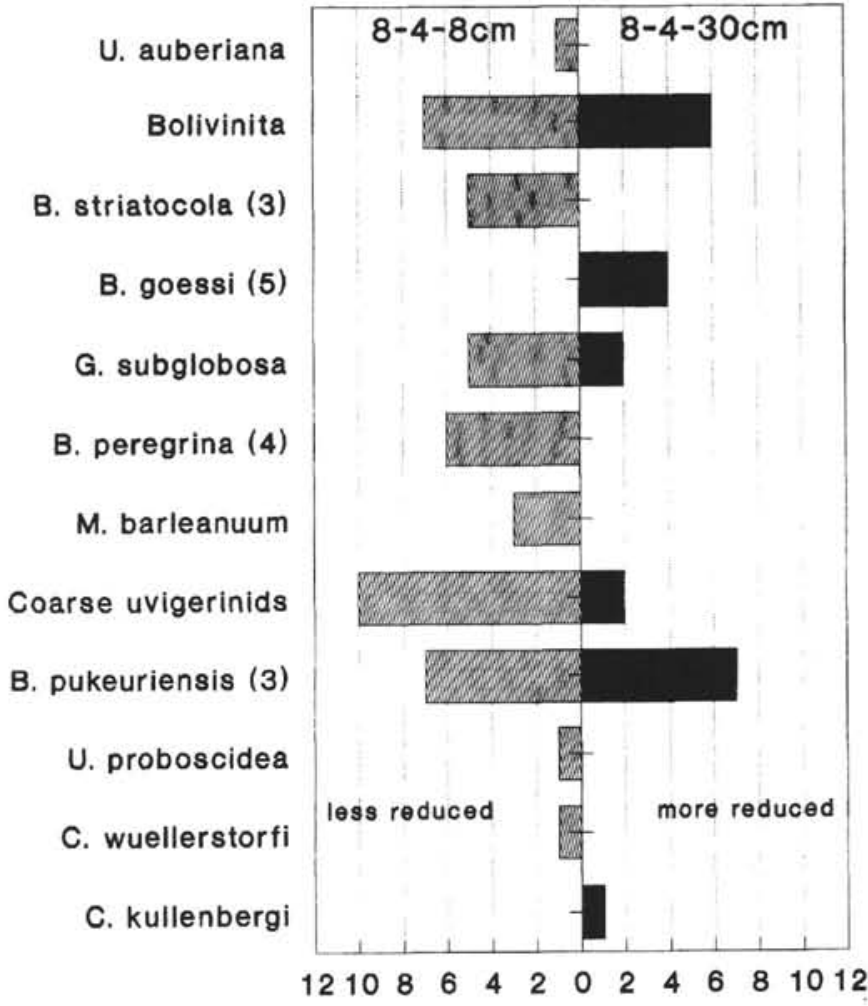

Figure 3. Benthic faunal abundances in two samples of middle Miocene Subzone CN5b (= Zone N13) from reduced levels in Core 115-714B$8 \mathrm{H}$. The upper sample $(115-714 \mathrm{~B}-8 \mathrm{H}-4,8 \mathrm{~cm})$ was light greyish green in color, whereas the lower sample $(115-714 \mathrm{~B}-8 \mathrm{H}-4,30 \mathrm{~cm})$ was dark greenish grey and is presumed to represent more reducing conditions (Backman, Duncan, et al., 1988). Benthic foraminifers include Uvigerina auberiana, Bolivinita quadrilatera, and Bolivina striatocola of Group 3, indicated in parentheses; Bolivina goessi of Group 5; Globocassidulina subglobosa and Bolivina peregrina of Group 4; Melonis barleanuum, all uvigerinids from the coarse fraction $(>250 \mu \mathrm{m})$, bolivinids with smooth walls and fine pores called Bolivina pukeuriensis of Group 3, Uvigerina proboscidea, Cibicides wuellerstorfi, and Cibicidoides kullenbergi. Count data are listed in Boersma (this volume). Zonation from Figure 2 .

Group 5 (Plate 4) is an amalgam of morphological types, all of which are typified by cigar-shaped, flat tests; broad, flat chambers; and a tendency for the final chamber to be added uniserially. Some have moderately arched sutures, others have straight sutures typical of Group 3 species. Pores vary from minute to very large. When the pores become large, the test also becomes larger, low crenulations begin to form, and the test becomes thicker in cross-section. Species lumped into this category include Bolivina pukeuriensis, Bolivina finlayi, and Bolivina pulchra, which best exemplifies the general features of the group.

\section{History of Miocene-age Bolivinids at Site $\mathbf{7 1 4}$}

At the beginning of the Miocene (Subzone CN1a-Zone CN3), bolivinids are moderately abundant and diverse. Most abundant are moderately crenulate species of Group 4, although forms with medium-sized pores of Group 2 , including $B$. pusilla, are frequent. Toward the top of this interval, a few specimens of the finely porous $B$. pukeuriensis of Group 5 appear in small numbers. 
In the uppermost lower to lower middle Miocene (Zones CN3-CN4 = Zones N8-N11), bolivinids become scarce and less diverse, and the small faunas are dominated by finely porous individuals, largely attributable to $B$. pukeuriensis from Group 5, with less common B. pseudoplicata and B. peregrina (Fig. 4). In these levels all bolivinid species are fairly delicate and finely porous. This interval is followed by one peak of the smoother species with small- to medium-sized pores, $B$. arta and $B$. pseudogemma from Group 3, around $74 \mathrm{~m}$ (attributed to Subzone $\mathrm{CN} 5 \mathrm{a}=$ Zone N12). Beginning around $69 \mathrm{mbsf}$ (Subzone $\mathrm{CN} 5 \mathrm{~b}=$ Zone N13), as bolivinids become more diverse and abundant, species from Groups 2, 4, and 5 become equally abundant. Bolivina pulchra becomes thicker and develops very large pores during this interval, B. pseudoplicata and Bolivina hebes become common for the first time, and a small, finely porous, and delicate, multichambered, elongate form of $B$. goess $i$ proliferates. With the exception of the elongate $B$. goessi, which does not occur downhole, species in Subzone CN5b have larger pores than in previous levels.

A third faunal episode extending from 54 to $39 \mathrm{mbsf}$ (Zone $\mathrm{CN} 7-$ Subzone $\mathrm{C} 7 \mathrm{~b}=\mathrm{N} 16$ ) involves maximal bolivinid diversity and abundance and the consistent dominance of the crenulate bolivinids of Group 4 (Fig. 4). This interval ends at $36 \mathrm{mbsf}$ (Zone $\mathrm{CN} 8$ = Zone N16) when bolivinid abundance and diversity begin to fluctuate from sample to sample. Near $26 \mathrm{mbsf}$ (Zone $\mathrm{CN} 8$ ), a new fauna in which bolivinids are abundant but very small in size, contains maximal numbers of Group 4 , with lesser numbers of $B$. pulchra with large pores. These faunas resemble their Pleistocene and modern analogs.

In two samples from the top of the hole, sediments are dark greenish brown in color, with greenish grey interlayers. Pleistocene bolivinids in Hole 714B are minute and less numerous than below, possibly as a result of improved preservation of fine fraction foraminifers. The darkest layer (Sample 115-714B-1H-1, 50 $\mathrm{cm}$ ) contains eight species of bolivinids, but the Group 4 species $B$. pseudoplicata is highly dominant. The accompanying benthic foraminifer fauna includes Cassidulina carinata, Triloculina lucernula, "Trifarina" pigmea, Bulimina alazanensis, Globocassidulina subglobosa, Bulimina marginata, and Uvigerina hispidocostata. Benthic foraminifers are uncommon, siliceous fossils are relatively common, and many benthic and planktonic foraminifers are undergoing severe dissolution. Globorotaliids are moderately abundant and some Globigerinoides ruber are present, suggesting deposition later in the upwelling, before or during the warmest phase of an upwelling event, or at the edge of an upwelling zone (Kroon and Ganssen, 1988).

In the lighter grey-green layer (Sample 115-714B-1H-5, 50 $\mathrm{cm}$ ), benthic foraminifers are infrequent but more numerous than in the overlying darker samples. Four bolivinid species are present, but Group 3 types are most common (Plate 2). This sample is better preserved and contains a much larger fine fraction, which does not contain many siliceous remains. Among the planktonic foraminifers, the globorotaliids are large and abundant, suggesting deposition early during an upwelling episode but during a large floral bloom (Kroon and Ganssen, 1988). Warm-water indexes are fewer than in the darker colored sample. The most common benthic foraminifers are Cibicidoides bradyi, Stilostomella subspinosa, Uvigerina auberiana, and Globocassidulina subglobosa. The diverse, but not common, uvigerinids are represented by $U$. auberiana, Uvigerina proboscidea, Uvigerina pigmea (spinose), and the only known Pleistoceneage specimen of Uvigerina spinulosa (Boersma, this volume).

Reiterating then, at Site 714 the Miocene section from Zones $\mathrm{CN} 1$ to $\mathrm{CN} 7$ can be subdivided into five intervals with unique bolivinid populations:

1. In the lower Miocene (Zones CN1-CN2), crenulate forms of Group 4 predominate in moderately diverse faunas.
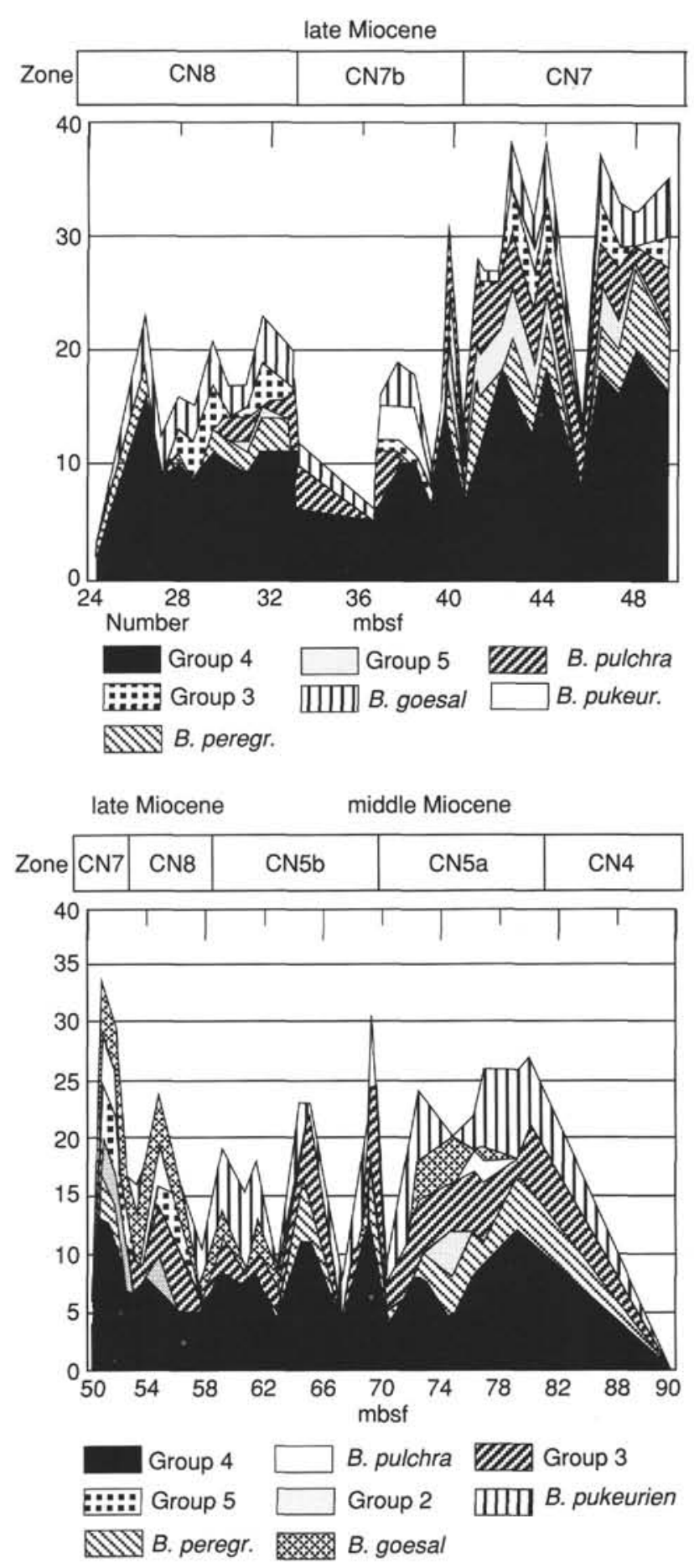

Figure 4. Relative abundances of the most common bolivinids in Hole 714B from middle into late Miocene. Bolivinids from Zones CN4 to $\mathrm{CN} 7$ include the crenulate forms of Group 4 plotted separately from the crenulate species tentatively attributed to Group $4, B$. peregrina; Group 1 species represented by $G$. goessi; all Group 3 species plotted together; and $B$. pukeuriensis and B. pulchra of Group 5 plotted separately from other species of Group 5. The same bolivinid species and groups are plotted from late Miocene Zones CN7-CN8. The bolivinid diversity peaks, associated with increased abundance of the crenulate Group 4 types from 52 to $39 \mathrm{mbsf}$, correspond to the interval of heightened primary production indicated by the diatoms. Count data are are listed in Boersma (this volume). Zonation from Figure 2. 
2. The lower to middle Miocene (Zones CN3-CN4) is characterized by low bolivinid abundance with the finely porous, flat forms of Group 5 predominating.

3. The middle to upper Miocene interval (Zone CN5-Subzone $\mathrm{CN} 5$ b) contains fluctuating, moderately diverse faunas dominated by crenulate types of Group 4, occasionally more abundant Group 3 species, and forms with larger pores.

4. In upper Miocene Zone CN7 to Subzone CN7b, there is an episode of maxima in bolivinid diversity, abundance, and numbers of crenulate species of Group 4 and B. pulchra of Group 5.

5. In uppermost Zones $\mathrm{CN} 7-\mathrm{CN} 8$, faunas contain lower numbers of large-sized bolivinids, but abundant crenulate forms of Group 4 in the finest fractions $(>63-<125 \mu \mathrm{m})$.

\section{OTHER BENTHIC INDEXES}

To test whether bolivinid abundance and diversity were related to lowered oxygen concentrations, several other parameters depicting oxygenation and organic carbon preservation at the bottom were considered. Under low-oxygen conditions, less organic carbon should be oxidized and indexes related to organic carbon flux to the sediment should be present. One such index is the infaunal benthic foraminifer genus Uvigerina, the abundance of which has been related to higher levels of labile organic carbon in sediments, lower levels of oxygen at the bottom, increased carbonate sedimentation rates under low-oxygen water masses, "aged" water masses, finer sediment with higher clay content, and specific concentrations of both oxygen and organic carbon (Douglas, 1981; Lutze and Coulbourn, 1983; Miller and Lohmann, 1983; Peterson, 1984; Boersma, 1985). Uvigerinids are also among the more solution susceptible benthic foraminifers (Corliss and Honjo, 1980).

Uvigerinids in Hole 714B (Fig. 5) are infrequent during the middle Miocene, become more common in the upper Miocene, and peak in abundance in upper Miocene Zone CN7-Subzone $\mathrm{CN} 7 \mathrm{~b}$ from 51 to 39 mbsf. Coarse fraction uvigerinids ( $>250$ $\mu \mathrm{m}$ ) compose a lower peak, near 84 mbsf (Zone CN4), and a second near 69 mbsf (Subzone CN5b) in the strongly reduced Sample 115-714B-8H-4, $30 \mathrm{~cm}$ (Fig. 3).

Uvigerinids and bolivinids vary inversely in the lower to middle Miocene; then both reach abundance peaks during Zone CN7-Subzone CN7b (Fig. 5). The inverse relationship is particularly evident near 69 mbsf, where uvigerinids reach their middle Miocene abundance maximum and bolivinids decrease in number. Above $39 \mathrm{mbsf}$ both groups decrease in abundance, but bolivinids continue to be frequent in fine fractions $(>63-<125$ $\mu \mathrm{m})$. Because a standardized sample was counted, their abundance is masked because of the improved preservation of finefraction foraminifers in the upper part of Hole 714B.

Because infaunal number and diversity of deep-sea benthic foraminifers have been related to elevated organic carbon flux to the bottom, together with food-dependent predation pressure (Rex, 1976; Corliss and Chen, 1988; Graf, 1989), the numbers of infaunal vs. epifaunal species and species richness were computed. Figure 6 depicts the elegant, direct relations among infaunal number, total bolivinid number, and total benthic foraminifer diversity through the middle and upper Miocene in Hole 714B. Clearly, infaunal number, diversity, and bolivinid abundance all fluctuate synchronously and in parallel throughout the section, with maxima at 39 and 51 mbsf bracketing an episode of generally higher values and minima concentrated at 65-59 mbsf. One lower abundance peak is located at $66 \mathrm{mbsf}$.

\section{SILICEOUS FOSSIL STUDIES}

Surface-water productivity acts as a primary control on the abundance of diatoms in sediments by controlling the silica saturation level of pore waters (Molina-Cruz and Price, 1977;
Leinen, 1979; Pokras and Molfino, 1986). Variations in diatom abundance at Site 714 , therefore, approximate primary-productivity changes in the southern Indian upwelling zone. Diatom abundance increases throughout the section in Hole 714B (Fig. 7). Diatoms are absent in the lower Miocene, first appear around $13 \mathrm{Ma}$ at Site 714, increase in abundance between 56 and 54 mbsf (Zones CN6-CN7), and decrease in abundance between 31 and 34 mbsf (upper Subzone CN7b to Zone CN8). Maxima bracket this higher abundance interval. Diatoms become abundant in one episode near 66 mbsf (Subzone CN5b), accompanying high numbers of infauna, uvigerinids, and elevated benthic foraminifer diversity (Fig. 6).

Information on primary productivity is derived from pennate diatom species of the genera Thalassionema and Thalassiothrix, hereafter called the Thalassionema group. These forms thrive in areas with vigorous ocean circulation, usually regions of sustained upwelling (Schuette and Schrader, 1981). The record of the Thalassionema group in Hole 714B parallels that of overall diatom abundance; the group increases above the 54-56 mbsf level and decreases again above 34-32 mbsf, but one lower peak is found near 66 mbsf (Fig. 7) when diatoms, uvigerinids, infauna, and benthic foraminifer species richness all increase (Fig. 6).

The diatom species Coscinodiscus marginatus is a cold-water form; its presence indicates open communication between lowand high-latitude, surface-water diatom assemblages. In Hole 714B this species appears abruptly at $64 \mathrm{mbsf}$, and it remains a common constituent of the diatom assemblages throughout the section up to 47 mbsf. At this point, it decreases in abundance and then continues in low abundance to near 32 mbsf (Fig. 7).

Sponge spicules and radiolarians are more solution resistant than diatoms. A part of their abundance fluctuation, therefore, represents varying dissolution stages of the siliceous assemblage. Sponge spicules may also predominate at the edge of upwelling zones. Sponge spicules are a common constituent of the Miocene siliceous assemblages in Hole 714B, especially in the middle Miocene where other siliceous fossils are uncommon (Fig. 7). Spicules become more common between 86 and $70 \mathrm{mbsf}$, are generally frequent between 60 and $34 \mathrm{mbsf}$, and peak again at 26 mbsf. Radiolarians are frequent in the middle Miocene, but they increase coevally with diatoms in the interval from 56 to 54 mbsf; they again decrease in abundance between 52 and 50 mbsf. A second abundance peak is located at 26 mbsf together with that of the spicules (Fig. 7).

\section{STABLE ISOTOPE STUDIES}

Stable isotope values of benthic and planktonic foraminifers were measured with the expectation that they would reflect local upwelling episodes and temperature changes (Shackleton and Kennett, 1975; Elmstrom and Kennett, 1985; Zahn et al., 1986). Fluctuations in all isotope ratios were small. Planktonic oxygen isotope ratios (Fig. 8) ranged from approximately $-1.9 \%$ to $-2.0 \%$ throughout the section, but they became most enriched $(-1.48 \%$ ) near $67 \mathrm{mbsf}$ in an interval of enriched values from 69 to 67 mbsf. Most of the depleted values $(-2.53 \%)$ were registered above at $54 \mathrm{mbsf}$.

Benthic oxygen isotope values gradually became more enriched through the studied section (Fig. 8). Below $60 \mathrm{mbsf}$ values averaged $2.5 \%$, increased to averages near $2.7 \%$ from 60 to $40 \mathrm{mbsf}$, and then displayed heavier values from $2.8 \%$ to $2.9 \%$ above 39 mbsf. The highest ratios were clustered from 39 to 31 mbsf, and most depleted values $(2.49 \%$ ) occurred at $64 \mathrm{mbsf}$.

The surface-to-bottom oxygen isotope gradient achieved a minimum near $69 \mathrm{mbsf}$ and a maximum at $50 \mathrm{mbsf}$. The minimum surface-to-bottom gradient at 69 mbsf was the result of enriched planktonic oxygen isotope values, but near average benthic oxygen isotope ratios. 


\section{Miocene}

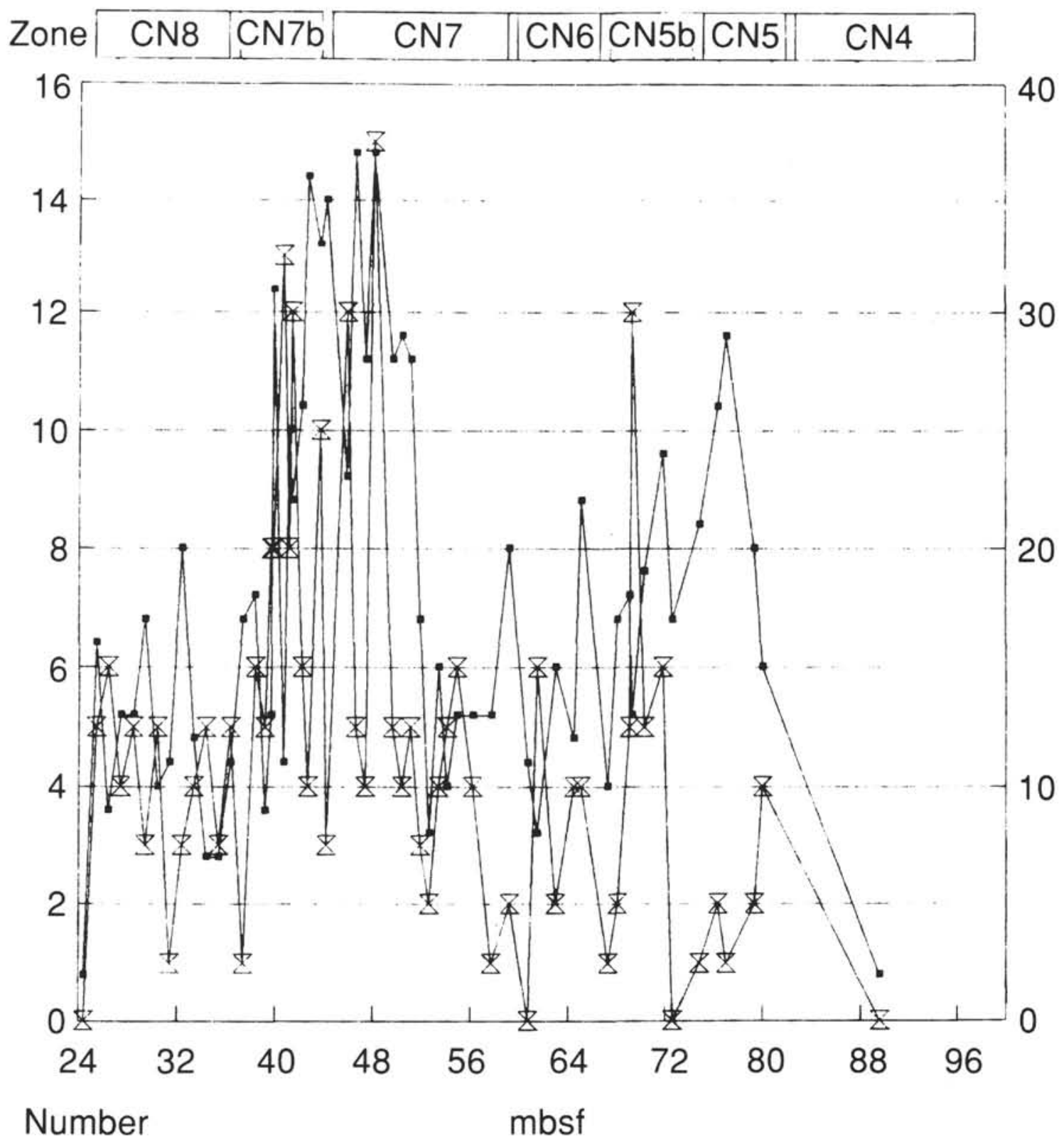

- Bolivinids

$\varangle$ Total uvigerinids

Figure 5. Total uvigerinid abundance vs, total bolivinid abundance from the $>63-\mu \mathrm{m}$ size fraction in the middle to upper Miocene in Hole 714B. Increased bolivinid abundance and diversity suggest development of a mid-depth oxygen minimum (Poag and Low, 1984). High abundances of uvigerinids have been related to elevated organic carbon content in sediments (Douglas, 1981). Count data are listed in Boersma (this volume). Zonation from Figure 2.

A comparison of bolivinid abundances with oxygen isotope gradients in the water column indicates a relationship between more enriched, near-surface oxygen isotope values and bolivinid peaks from 80 to $66 \mathrm{mbsf}$ as well as at the beginning of the bolivinid abundance episode from 51 to $42 \mathrm{mbsf}$. There is a clear correspondence between the largest shift from more depleted to more enriched planktonic oxygen isotope values between 54 and
$51 \mathrm{~m}$ and the beginning of high bolivinid abundance. Planktonic oxygen isotope values again become more depleted several meters below the drop off in bolivinid abundance and diversity near 39 mbsf.

Benthic oxygen isotope values are more depleted during the bolivinid maximum episode (54-39 mbsf) when planktonic oxygen isotope values are more enriched (Fig. 8). Benthic oxygen 

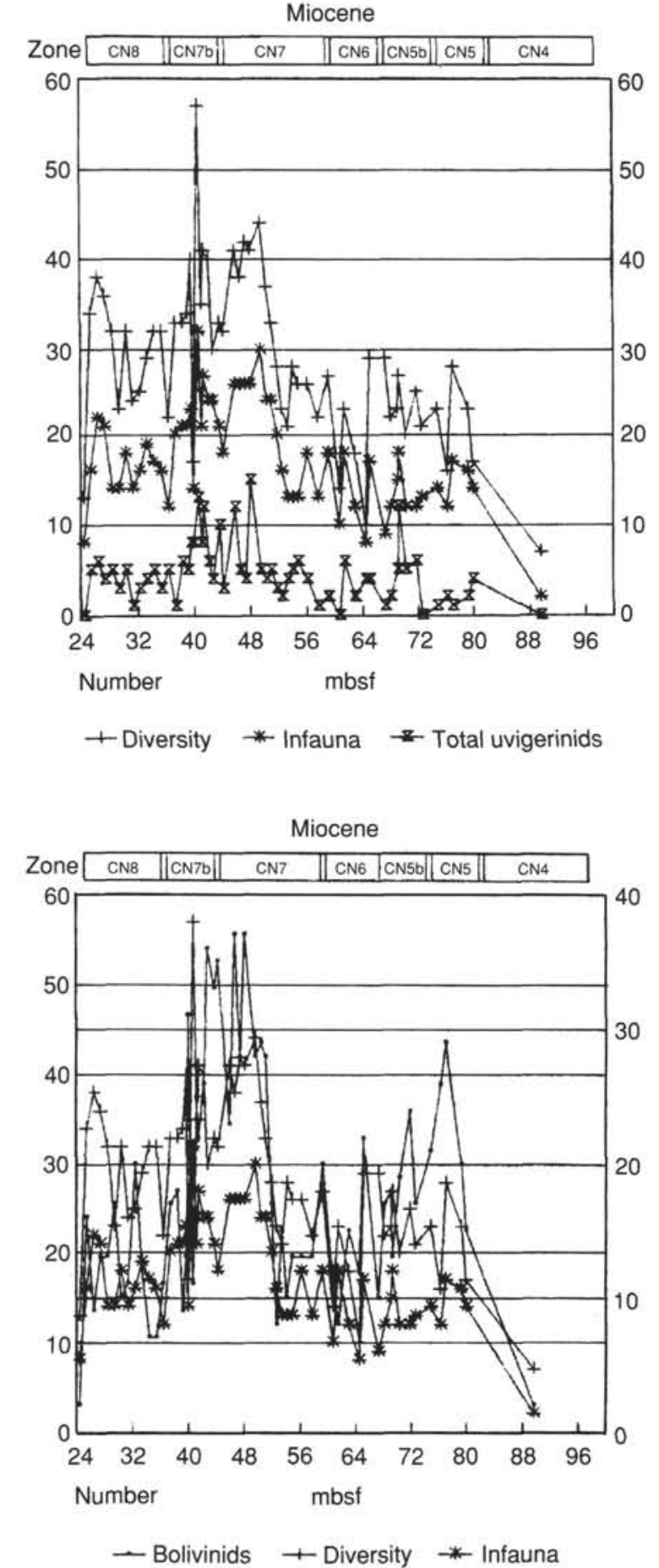

Figure 6. Relative numbers of uvigerinids, bolivinids, infaunal species, and benthic foraminifer species richness from the middle to upper Miocene in Hole 714B. Diversity (species richness) is scaled to the left; total number of infauna, bolivinids, and uvigerinids, to the right. Both the bolivinids and uvigerinids fluctuate synchronously and in parallel with infaunal number and species richness. Maxima occur in all indexes during the high-productivity episode from 51 to 39 mbsf. Because all indexes fluctuate synchronously through this interval, they may be responding to the same causal mechanism. Count data are listed in Boersma (this volume). Zonation from Figure 2. isotope values are more enriched during times when bolivinids are less frequent.

In the modern southern Indian upwelling zone, the surfaceto-bottom carbon isotope differential has been related to upwelling location and intensity; the gradient diminishes as a result of depletion of benthic values, but relatively constant values of Globigerinoides in areas or times of more intense upwelling. After the phytoplankton blooms, however, planktonic values also become more depleted as light carbon is recycled to the ocean surface (Kroon and Ganssen, 1988). At Site 714 there is a direct correspondence between the surface-to-bottom carbon isotope gradient and bolivinid abundance (Fig. 9): the carbon isotope gradient is narrower when uvigerinids and bolivinids are most abundant and diverse, and vice versa (Fig. 10). The carbon isotope gradient averages $1.00 \%$ below $54 \mathrm{mbsf}$, decreases to an average near $0.8 \%$ from 54 to 50 mbsf, then increases to maximal values at 39 mbsf. In contrast to the modern situation, at Site 714 the carbon isotope gradient decreases because near-surface values become depleted and bottom values become slightly enriched.

Carbon isotope ratios of the benthic cibicidids, in particular Cibicides wuellerstorfi, may represent water-mass "aging" and relative oxygenation of bottom waters (Boersma and Shackleton, 1977; Woodruff and Savin, 1989). Although there is no peak-to-peak correspondence, generally the carbon isotope values of Cibicides, an epifaunal genus, are more depleted when bolivinids are more frequent (Fig. 11). Carbon isotope ratios of Cibicides spp., which average $0.6 \% 0-0.7 \%$, are lowest during the bolivinid maxima from 48 to $39 \mathrm{~m}$, but the carbon isotope depletion lags behind the bolivinid increase (at $51 \mathrm{mbsf}$ ) by several meters. High values, with a maximum near $1.7 \%$, characterize samples from Zone CN4.

Zahn et al. (1986) have proposed that the carbon isotope differential between Uvigerina and Cibicides may reflect organic carbon oxidation in sediments under upwellings. The greater the amount of organic carbon being oxidized within the top few centimeters of sediment, the more ${ }^{12} \mathrm{C}$-enriched carbon is returned to pore waters (McCorkle et al., 1985), and the greater the carbon isotope differential between the infaunal uvigerinids and the epifaunal cibicidids. Although we have relatively few uvigerinid measurements, the differential is small, averaging $0.7 \%$. Carbon isotope ratios of Cibicides and Uvigerina fluctuate together and become slightly lower from the middle to upper Miocene (Fig. 11), are lowest above 69 mbsf during the bolivinid and uvigerinid abundance maxima, and are higher again near 29 mbsf (Table 1). The largest Cibicides-Uvigerina gradient is measured at $39 \mathrm{mbsf}$ at the end of the high abundance episode of bolivinids and uvigerinids when the surface-'o-bottom carbon and oxygen isotope gradients are at their maxima.

\section{DISCUSSION}

Today, the abundance and diversity of Bolivina species reflects the amount of oxygen at the seafloor or in the sediments at the time of deposition, with high diversities indicating lower (but not lowest) oxygen levels and higher percentages of organic carbon (Harman, 1964; Phleger and Soutar, 1973; Poag, 1981; Leutenegger and Hansen, 1979; Douglas, 1981). Higher concentrations of Bolivina and organic carbon have also been related to the position of the oxygen minimum zone in the water column (Douglas and Heitman, 1979; Douglas, 1981; Sen Gupta et al., 1981; Poag and Low, 1984). Using bolivinids as tracers for the oxygen minimum zone, Poag and Low (1984) found a direct relation between bolivinid diversity and the oxygen minimum at intermediate depth Site 548 off the Irish continental margin in the Bay of Biscay. A bolivinid diversity increase here indicates initiation of an epibathyal oxygen minimum, related to 

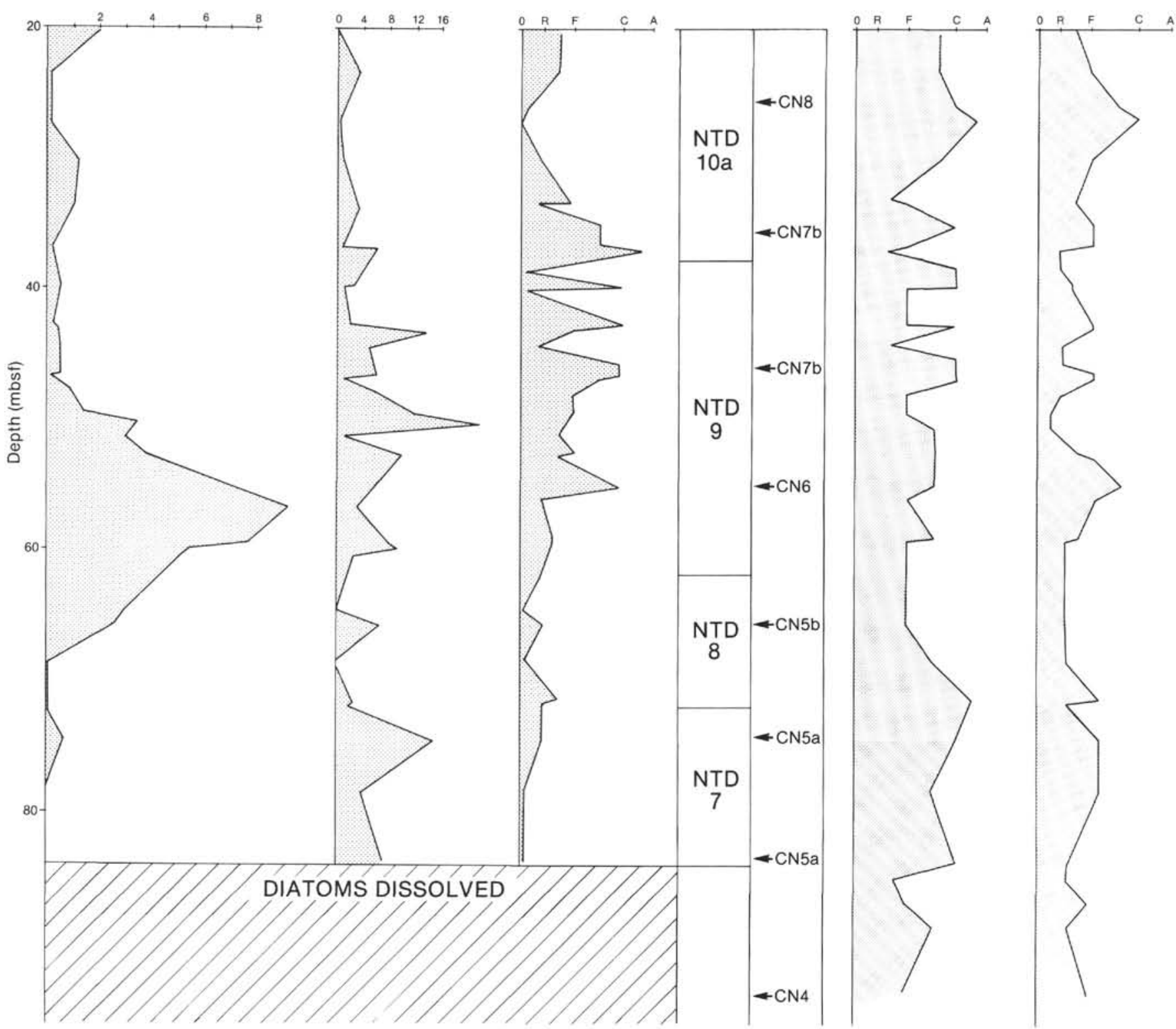

Figure 7. Abundances of siliceous fossils through the middle and upper Miocene in Hole 714B. The abundance of the cold-water diatom C. marginatus and of benthic diatoms is recorded as average number of specimens observed in a slide traverse. The abundance of Thalassionema, sponge spicules, and radiolarians is given relative to other particles on the slide. Abundances are recorded as absent $(-)$, rare (R, $<5 \%)$, few (F, $5 \%-30 \%)$, common (C, 30\%-60\%), and abundant (A, > 60\%). The abundance of Thalassionema and the preservation of diatoms from 54 to $32 \mathrm{mbsf}$ have been related to increases in surface-water primary productivity. Count data are listed in Mikkelsen (this volume). Zonation from Figure 2.

the presence of Mediterranean Outflow Water (MOW), around $10 \mathrm{Ma}$.

The southern Indian upwelling zone is an ideal location to test the use of bolivinids as tracers of low-oxygen waters or bottom conditions. In the northern Indian Ocean, low-oxygen intermediate water masses are generated by the slow advection of intermediate waters and the closed nature of the northern Indian Ocean, which has no connection to northern higher latitude waters (Wyrtki, 1973). Modern upwelling tends to elevate the low-oxygen water mass up near the surface and onto the slope, where organic carbon is then preserved, resulting in the accumulation of laminated sediments today (Banse, 1968). Far- ther offshore in the Arabian Sea and Central Indian Basin, suspended loads from the Indian continental margin and the Bengal Fan are deposited as far south as Sites 215 and 216 on Ninetyeast Ridge (von der Borch, Sclater, et al., 1974). Thus, both upwelling and detrital sedimentation contribute organic carbon to sediments in the oxygen minimum in the southern Indian upwelling zone.

The history of bolivinids in this area should depict the oxygenation of the infaunal habitat under this upwelling zone. By the early Neogene $(\mathrm{CN} 1 \mathrm{a}-\mathrm{CN} 2$ = Zone N4), moderate bolivinid diversity and abundance and the predominance of Group 4 crenulate types with their coarse pores suggest moderately oxic con- 

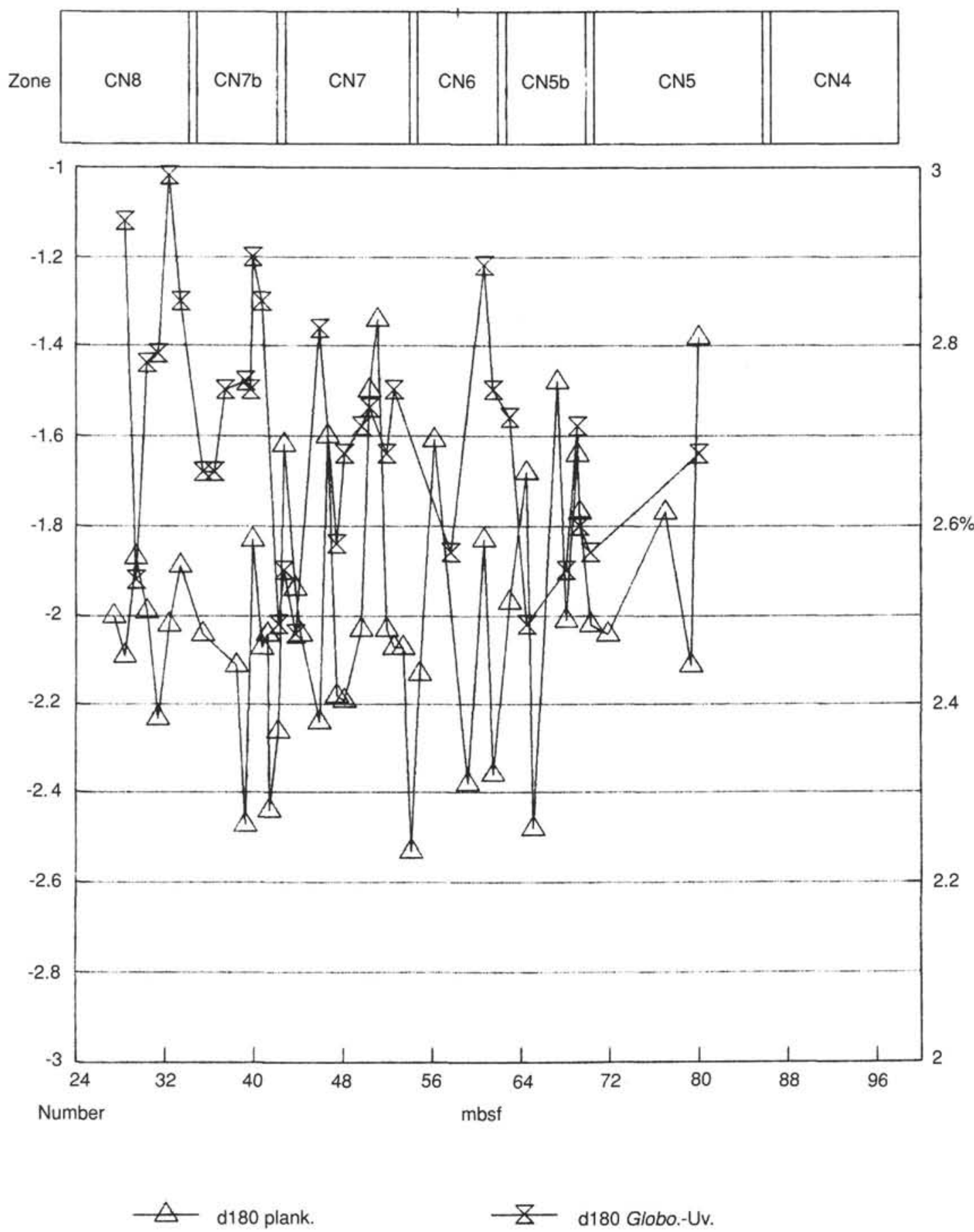

Figure 8. Oxygen isotope ratios of benthic and planktonic foraminifers from the late Miocene in Hole 714B. Surface curves are based on measurements of Globigerinoides sacculifer; benthic curves, on species of Uvigerina and Globocassidulina. Data were provided by N. J. Shackleton and M. Hall, Cambridge University (Table 1). Zonation from Figure 2.

ditions in the sediment. Poag and Low (1984) also register oxygenated conditions through this interval on the Irish continental margin.

During the early to earliest middle Miocene time interval (Zone CN3-CN4) at Site 714, low bolivinid and uvigerinid abundances and the predominance of finely porous individuals of Group 5 indicate reduced organic carbon accumulation and less well oxygenated conditions in these totally calcareous sediments. The ${ }^{13} \mathrm{C}$-enriched benthic carbon isotope ratios, however, suggest the presence of oxygenated or "new" bottom waters. Poag and Low (1984) register oxygenated conditions through this interval on the Irish continental margin.

Beginning in middle Miocene Subzone CN5a, increased bolivinid abundances, the development of larger pores in several 


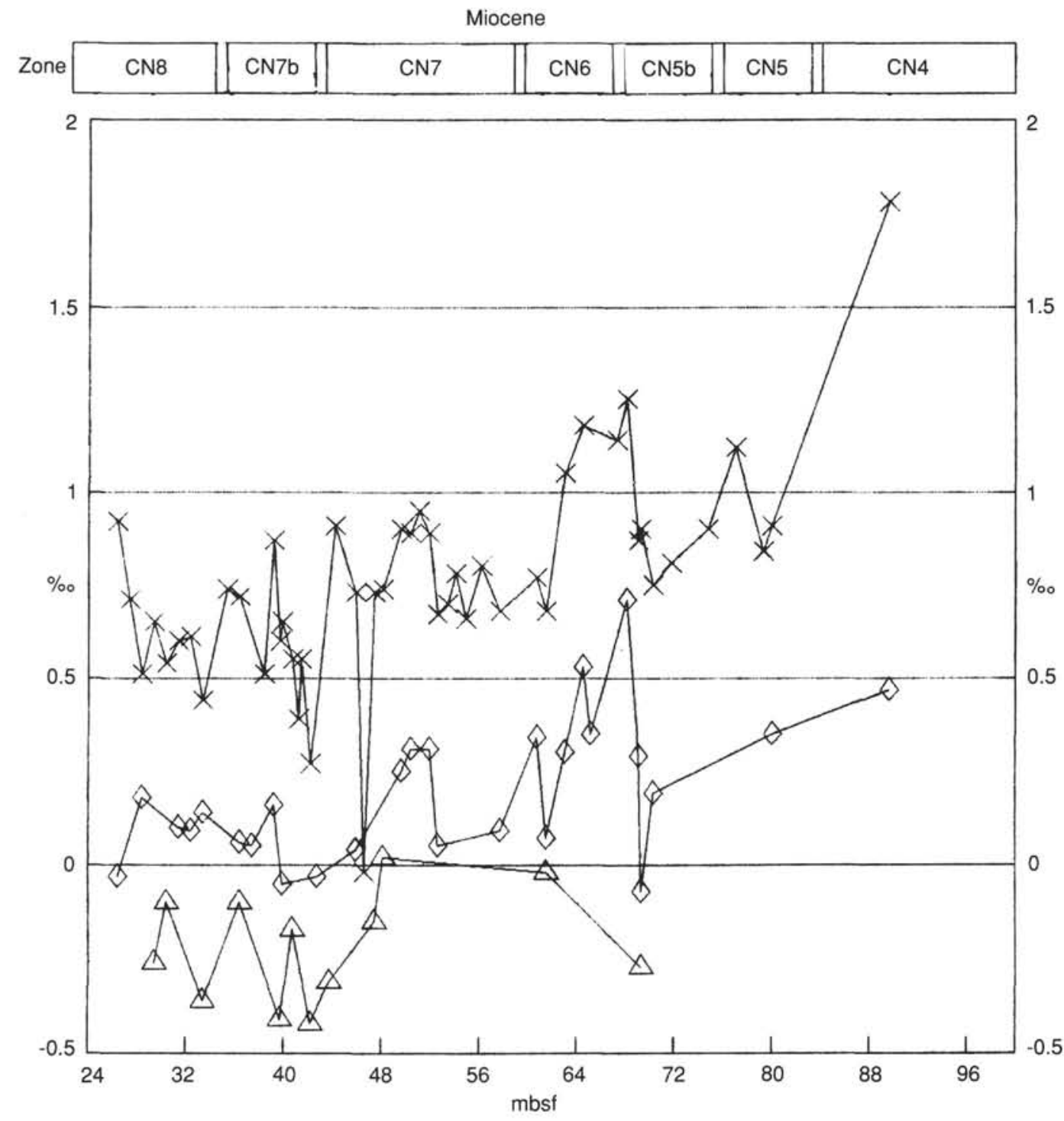

Number

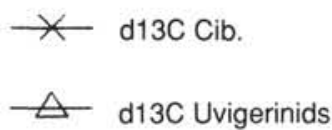

$\curvearrowright$ d13C Globocass.

Figure 9. Carbon isotope ratios of benthic cibicidids and planktonic foraminifers in the late Miocene in Hole 714B. Surface curves are based on Globigerinoides sacculifer; benthic curves, on species of Cibicides and Planulina. In the southern Indian upwelling zone, diminished surface-to-bottom ${ }^{13} \mathrm{C} /{ }^{12} \mathrm{C}$ gradients have been related to increased upwelling intensity or upwelling during a large floral bloom (Kroon and Ganssen, 1988). Stable isotopes are scaled on the left, and bolivinids on the right. Measurements were provided by N. J. Shackleton and M. Hall, Cambridge University (Table 1). Zonation from Figure 2.

species, and the dominance of Group 4 types with small tests, crenulations, and large pores, all suggest more aerated conditions in the sediments. This was a period of relatively high sea levels, interrupted by pulses of terrigenous deposition across the early/middle Miocene boundary on the Irish continental margin (Poag and Low, 1984). Bengal Fan sedimentation commenced delivery of clay-sized terrigenous material as far south as Sites
216 and 217 also in the middle Miocene (von der Borch, Sclater, et al., 1977). Monsoonal upwelling off the Maldives and the upwelling off Arabia both increased in the middle Miocene (Whitmarsh, Weser, et al., 1974).

In Subzone CN5a-Zone CN7 (N9-16), zonal interval, fluctuating bolivinid and uvigerinid abundances and moderate diversities, combined with the continuing dominance of Group 4 

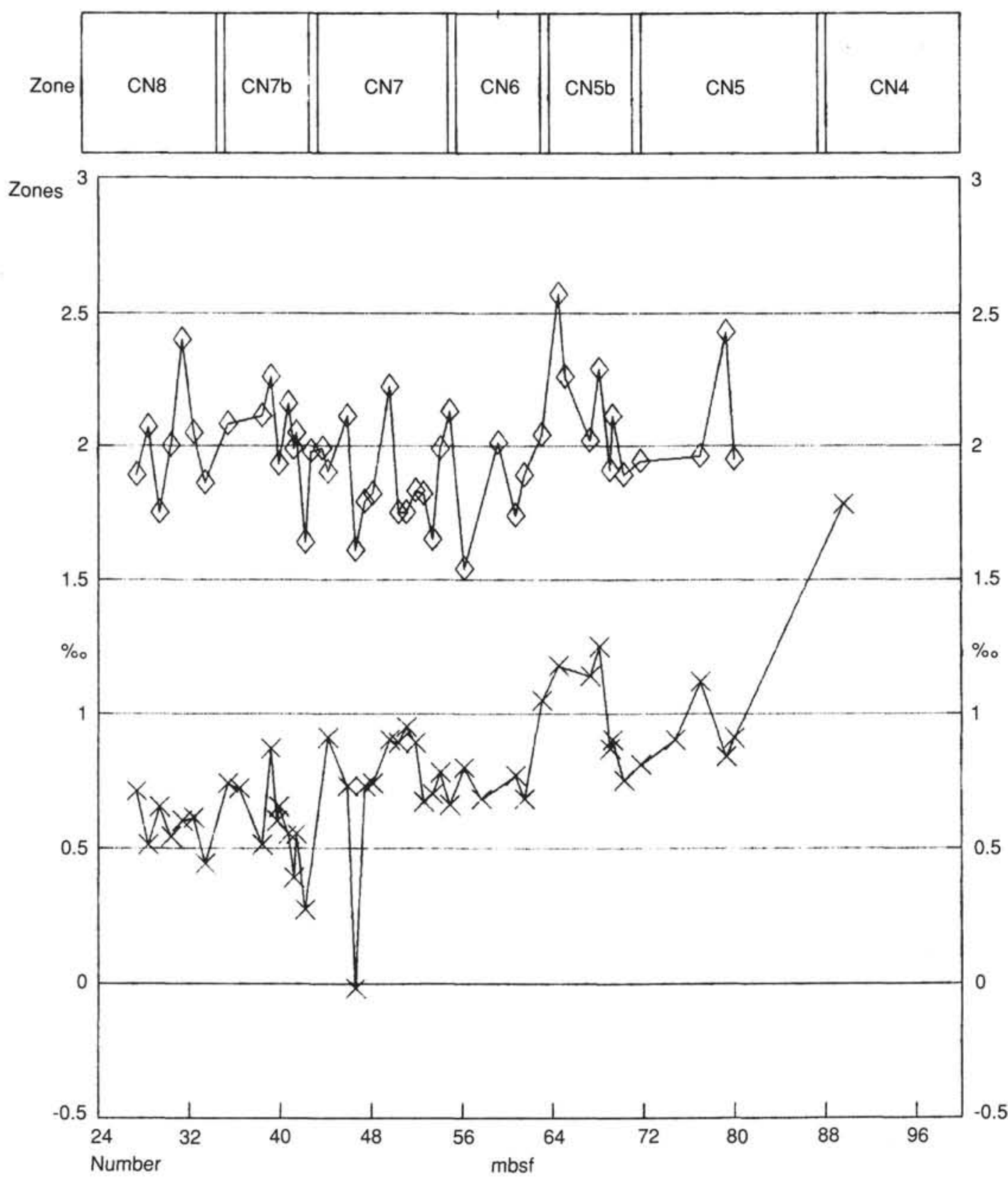

$\because \quad-\quad$ d13c cib. $\quad-\quad$ d13c planktonic

Figure 10. Abundance of uvigerinids plotted with the carbon isotope differential between the surface-dwelling species G. sacculifer and the benthic species Cibidides or Planulina. This differential was calculated by subtracting the benthic from the planktonic carbon isotope ratios. In the southern Indian upwelling zone, a diminished surface-tobottom carbon isotope gradient has been related to increased upwelling intensity or upwelling during the phytoplankton blooms (Kroon and Ganssen, 1988). Elevated uvigerinid abundance suggests higher organic carbon concentrations in the shallow infaunal habitat (Douglas, 1981; Corliss and Chen, 1988). Data were provided by N. Shackleton and M. Hall, Cambridge University (Table 1). Zonation from Figure 2. 

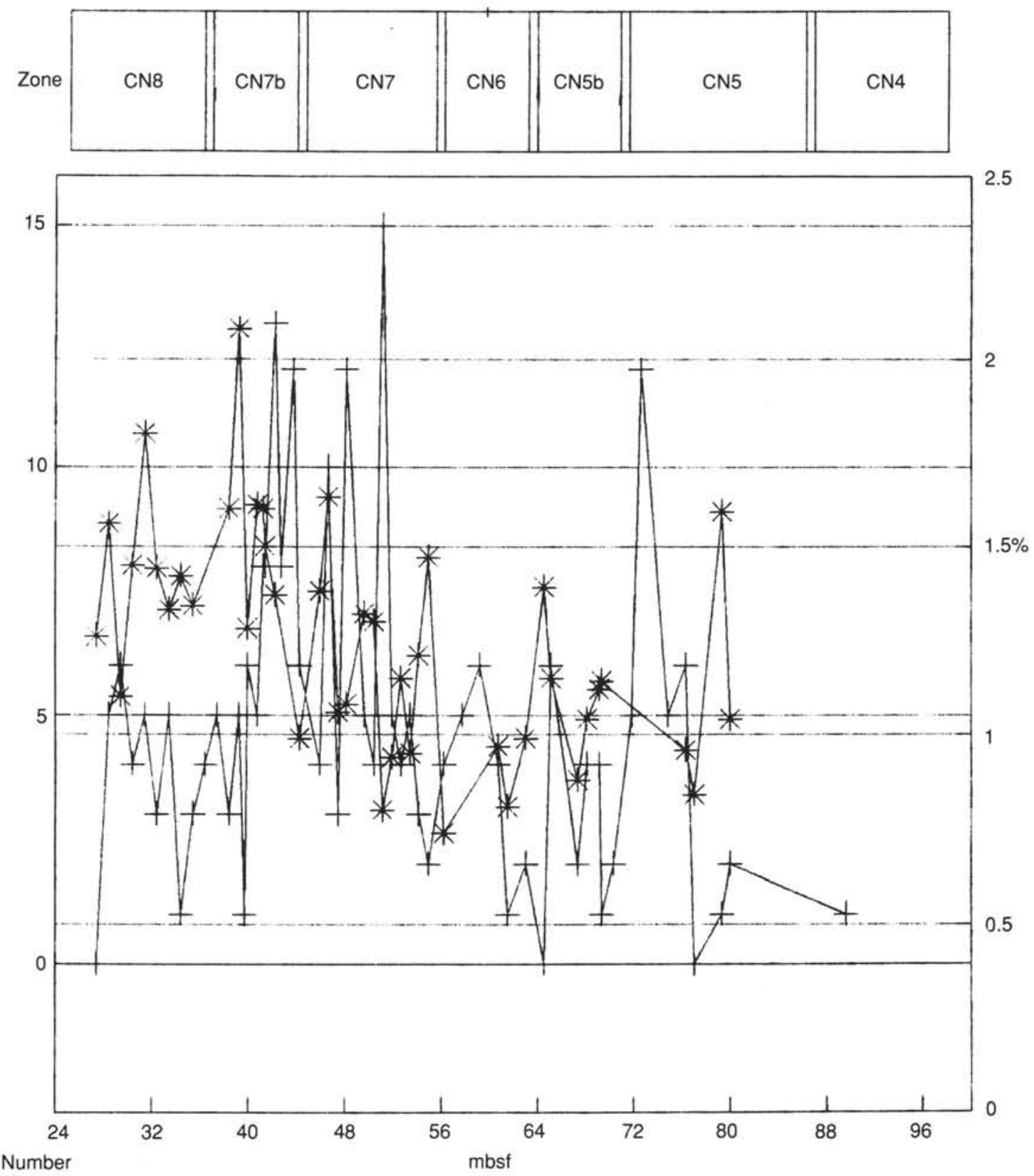

2.5

$.5 \%$

Number

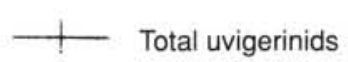

Figure 11. The carbon isotope differential between Cibicides or Planulina, Uvigerina, and Globocassidulina. According to Zahn et al. (1986), the larger the Cibicides-Uvigerina differential is, the more the organic carbon being oxidized in the top 1-2 cm of the sediments under upwellings. Globocassidulina data are shown for comparison, as this genus apparently occupies the upper infaunal habitat together with the uvigerinids, but may represent conditions of slightly lower food availability (Corliss and Chen, 1988; Boersma, this volume). Data were provided by N. J. Shackleton and M. Hall, Cambridge University (Table 1). Zonation from Figure 2.

bolivinids, indicate organic-carbon rich, but aerated, conditions in the sediments. In Subzone CN5b (= N13) within the darkest colored, most reduced sediments, however, the presence of delicate, finely porous types, and the uvigerinid abundance maxima at 69 mbsf suggest enhanced organic carbon accumulation and the development of an oxygen minimum in the sediments. These delicate, thin-shelled bolivinids, represented at Site 714 by the small, elongate $B$. goessi types, are indicative of high food avail- 
ability in low-oxygen settings (Phleger and Soutar, 1973). As at the top of Hole 714B, middle Miocene sediments are more reduced and darker in color in times or areas of cool upwelling.

Unaccompanied by any change in benthic ratios, planktonic oxygen isotope ratios are highest at $67 \mathrm{mbsf}$, suggesting coolest surface-water conditions immediately before the first abundance peak of $C$. marginatus at $66 \mathrm{mbsf}$. This data confirms that $C$. marginatus is an index for cooler water conditions at the surface, registered first here in Subzone CN5b (Zone N13). Cooling of surface waters suggests increased delivery of cooled, subsurface waters to the surface in the upwelling zone (Kroon and Ganssen, 1988). Thus, C. marginatus may also be an index of the initiation of upwelling or upwelling intensity.

\section{High-productivity Episode around $10 \mathrm{Ma}$}

In Zone CN7/Subzone CN7b time, dated around $10 \mathrm{Ma}$ (= Zone N16), the episode involving maximal uvigerinid, infaunal, and bolivinid abundances and highest bolivinid diversity (Figs. 4,5 , and 6) corresponds with a lithologic change to green colors, indicating moderately reducing conditions (Backman, Duncan, et al., 1988). This episode, first registered between 56 and $54 \mathrm{mbsf}$, was associated with the warming of surface-water temperatures to their upper Miocene maximum (Fig. 8) and with decreased abundance of the cool-water diatom index C. marginatus. Bolivinid and uvigerinid faunas, the bolivinid diversity maximum, and the preservation of abundant diatoms at Site 714 indicate heightened primary productivity and the development of a mid-depth oxygen minimum. The continuing dominance of Group 4 bolivinids implies that the upper infaunal habitat was more aerated at this time.

The sedimentary record indicates increased detrital sedimentation and improved carbonate preservation throughout this interval. The amount of detrital clays increases at Central Indian Basin Site 238 farther to the south during this 10-Ma event (von der Borch, Sclater, et al., 1974). Throughout the Indian Ocean, this was also the end of major carbonate dissolution in the Miocene (von der Borch, Sclater, et al., 1974).

Poag and Low (1984) recognize sedimentation in an epibathyal oxygen minimum zone throughout this same interval. They attribute this oxygen minimum to the extension of a water mass similar to modern MOW onto the Irish continental margin. Development of an upper-Miocene-age, intermediate-depth oxygen minimum attributed to increased deposition of organic carbon in the ocean, followed by improved carbonate preservation under lower oxygen bottom waters appear, however, to be global phenomena (Vincent et al., 1985; Boersma, 1985; Woodruff, 1985).

All indexes for heightened primary production increase through this time. Siliceous fossils-in particular, the Thalassionema index group for heightened surface-water productivity-become abundant for the first time, and the uvigerinids reach maxima from $\sim 54$ to $39 \mathrm{mbsf}$. For the first time, the rectuvigerinids are abundant enough to analyze isotopically (Table 1).

At this site, there is a clear parallel between the surface-tobottom carbon isotope contrast and diatom abundance. The surface-to-bottom carbon isotope gradient increases near $50 \mathrm{mbsf}$, remaining broad throughout the remainder of this episode. This gradient remains broad even after the bolivinid decrease, but it diminishes later in concert with the decrease of the productivityrelated Thalassionema group of diatoms and the cooling of surface-water temperatures.

A diminished surface-to-bottom carbon isotope differential of depleted near-surface and bottom values could result under conditions of heightened surface production. In this situation, depleted organic carbon is returned to the surface through upwelling from the intermediate oxygen minimum and to bottom waters via oxidation; thus, carbon isotope values in both areas should become more depleted (Elmstrom and Kennett, 1985; Kroon and Ganssen, 1988). At Site 714, however, the increased gradient results from the depletion of planktonic ratios and the enrichment of benthic values (Table 1). Although ${ }^{13} \mathrm{C}$-depleted organic carbon is being recycled to the surface, more oxygenated conditions or "newer" waters are being registered at the bottom.

The Cibicides-Uvigerina differential diminishes above $49 \mathrm{mbsf}$ when uvigerinid values become more depleted (Fig. 11), suggesting decreased organic carbon oxidation in the top layers of the sediments during the bolivinid-uvigerinid abundance maxima (Zahn et al., 1986). Together, uvigerinid abundance, the enriched carbon isotope values of Cibicidoides, and the benthic carbon isotope differential signal decreased organic carbon oxidation and increased organic carbon preservation in the top 1-2 $\mathrm{cm}$ of the sediments during the high-productivity episode. Interpretation of this ratio is problematic, however, and can be affected by the depth in the sediment at which organic carbon is accumulating and being oxidized (Jahnke et al., 1982).

Bolivinid indexes of Group 4, which predominate in this highproductivity interval along with numerous Group 5 types with large pores (Fig. 4), imply increased aeration of the infaunal habitat. Because bolivinids are infaunal, and ornamented infauna usually live in the top $1-2 \mathrm{~cm}$ of the sediment column, we can presume an aerated upper infaunal habitat in the top 1-2 $\mathrm{cm}$ of the sediment (Corliss and Chen, 1988).

There are several reasons why the infaunal habitat should become more aerated during an upwelling event. Because the deepsea environment is usually food-limited, oxygenation may play the major role in habitat partitioning. Where upwelling is stimulated by invigorated circulation with an influx of "newer," more oxygenated bottom waters (as suggested by the benthic carbon isotope values), the total benthic habitat may become more oxygenated, thus expanding niche space for such infaunal oxic indexes as the crenulate bolivinids of Group 4 and the large-pored types in Group 5.

Alternatively, bolivinids may be reflecting aeration of pore waters in siliceous-rich sediments. Comparison of carbon isotope gradients in abyssal carbonate oozes near the central $\mathrm{Pa}$ cific equator vs. clay and siliceous sediments approximately $11^{\circ} \mathrm{N}$ has shown that in the carbonate site pore-water oxygen goes to very low values within the top few centimeters of the sediment (McCorkle et al., 1985). There is a steep ${ }^{13} \mathrm{C}$ gradient in surficial pore waters and samples at $1-2 \mathrm{~cm}$ are $>1 \%_{0}$ lighter than overlying bottom waters. In the more siliceous sediments, however, pore waters remain oxygenated and the carbon isotope gradient is shallow, about $0.1 \% 0$ per centimeter of sediment. Thus, siliceous-rich sediments away from the equator may have a more oxic character in pore waters than carbonate-rich sediments at the equator (McCorkle et al., 1985). Although this mechanism could explain the presence of Group 4 bolivinids, the sediments at Site 714 are not strictly siliceous clays (Backman, Duncan, et al., 1988), and the carbon isotope gradient between Cibicides and Uvigerina is not so shallow as suggested by McCorkle's (1985) data.

A third possibility involves the carbon flux rate. Pore-waternutrient results from the central Pacific and California borderland have shown that as carbon flux increased, the amount of carbon degraded and the oxygen flux through the diffusive sublayer into the sediments increased (Jahnke et al., 1982; Archer et al., 1989). Operation of this process at Site 714 would explain all the fossil data. With increased primary production (indicated by increased diatom abundance), the carbon flux to the bottom increased (represented by high bolivinid diversity and abundance of the uvigerinids), causing the flux of oxygen into the sedi- 
ments to increase (suggested by increased bolivinid porosity). Clearly, this is a complex problem that cannot be resolved with the data from Site 714 .

\section{CONCLUSIONS}

Bolivinid abundance and diversity can be used together with other foraminifer and floral indexes to recognize times of high primary production in the South Indian upwelling zone. Increased abundance of infauna, benthic uvigerinids, especially the rectuvigerinids, together with the Thalassionema group of diatoms, and high bolivinid diversity signal increased primary productivity and delivery of organic carbon to bottom sediments, and the development of an intermediate oxygen minimum in middle Miocene Subzone CN5b $(\sim 17 \mathrm{Ma})$ and late Miocene Zone CN7-Subzone CN7b $(\sim 10 \mathrm{Ma})$.

The abundance of Coscinodiscus marginatus, a diatom indicative of open communication in surface waters between high and low latitudes, increases during times of cool surface waters, as indicated by oxygen isotope analyses of Globigerinoides sacculifer, but it decreases during surface-water warming. Because cool surface waters develop with the inception of upwelling in the southern Indian upwelling zone, $C$. marginatus may also serve as an index of the beginning of subsurface water-mass upwellings.

The episode of increased primary productivity indicated by the first proliferation of the Thalassionema group of diatoms occurs during an episode of warmer surface-water temperatures. Sediments associated with this warm upwelling are only moderately reduced, the darkest colors occurring during cool upwellings. It is during this episode in Zone CN7-Subzone CN7b that the proliferation of uvigerinids and bolivinids suggests enhanced organic carbon preservation at the bottom under an oxygen minimum.

The surface-to-bottom carbon isotope differential decreases during the high-productivity episode in Subzone CN7b because of a decrease of surface ratios and a slight increase of benthic ratios. This implies return of depleted carbon to the surface via upwelling, but not to bottom waters via oxidation of organic carbon. Bottom waters may have been more aerated or less "aged." The narrowed carbon isotope differential between Cibicides vs. Uvigerina suggests decreased organic carbon oxidation in the upper 1-2 $\mathrm{cm}$ of sediment during the high-productivity episode in Subzone CN7b.

Specific bolivinid morphotypes that have been related to increased oxygenation of bottom waters may have a more complex message. When sediment becomes more siliceous, pore waters inhabited by the infaunal bolivinids may become more aerated, even in an upwelling zone. In addition, when the organic-carbon-rain rate to the sediments increases and the depth of the aerated zone in the sediments shoals, more organic carbon is degraded and oxygen flux into the sediments increases. Crenulate, large-pored bolivinids may be indexes for relatively well-aerated pore waters in the upper infaunal habitat that result from one or both of these mechanisms.

\section{ACKNOWLEDGMENTS}

The authors would like to thank the Ocean Drilling Program for allowing them to participate on Leg 115. Funding for postcruise research was generously provided to A. Boersma by USSAC and by W. A. Berggren, Woods Hole. The Danish National Science Research Council financed the cruise participation for N. Mikkelsen. I. Premoli Silva graciously offered the use of the scanning microscope laboratory, and A. Rizzi, CNR of Milan, took the photographs. N. J. Shackleton and M. Hall of Cambridge University supplied the stable isotope analyses. The authors benefited from discussion with J. Backman, L. C. Peterson, P. Schwart, and B. Corliss.

\section{REFERENCES}

Archer, D., Emerson, S., and Smith, C., 1989. Direct measurement of the diffusive sublayer at the deep sea floor using oxygen microelectrodes. Nature, 340:623-626.

Backman, J., Duncan, R., et al., 1988. Proc. ODP, Init. Repts., 115: College Station, TX (Ocean Drilling Program).

Banse, K., 1968. Hydrography of the Arabian Sea shelf of India and Pakistan and effects of demersal fishes. Deep-Sea Res., 15:45-79.

Barron, J., 1985. Diatom paleoceanography and paleoclimatology of the central and eastern equatorial Pacific between 18 and 6.2 Ma. In Meyer, L., Theyer, F., Thomas, E., et al., Init. Repts. DSDP, 85: Washington (U.S. Govt. Printing Office), 935-945.

Bé, A., Harrison, S., and Lott, L., 1973. Orbulina universa in the Indian Ocean. Micropaleontology, 19:150-192.

Boersma, A., 1985. Biostratigraphy and biogeography of Tertiary bathyal benthic foraminifers: Tasman Sea, Coral Sea, and on the Chatham Rise (Deep Sea Drilling Project, Leg 90). In Kennett, J. P., von der Borch, C. C., et al., Init. Repts. DSDP, 90, Pt. 2: Washington (U.S. Govt. Printing Office), 961-1037.

Brun, L., Chierici, M., and Meijer, M., 1984. Evolution and morphological variations of the principal species of Bolivinitidae in the Tertiary of the Gulf of Guinea. Geol. Mediterr., 11:13-57.

Corliss, B., and Chen, T., 1988. Morphotype patterns of Norwegian Sea deep-sea benthic foraminifera and ecological implications. Geology, 16:716-719.

Corliss, B., and Honjo, S., 1980. Dissolution of deep-sea benthonic foraminifera. Micropaleontology, 27:356-378.

Douglas, R., 1981. Paleoecology of continental margin basins: a modern case history from the borderland of Southern California. Depositional Systems of Active Continental Margin Basins, SEPM, Pacific Section, Short Course, 121-156.

Douglas, R., and Heitman, H., 1900. Slope and basin benthic foraminiferal of the California Borderland. In Doyle, L., and Pilkey, O. (Eds), Geology of the Continental Slopes. Spec. Publ., Soc. Econ. Paleontol. Mineral., 27:231-246.

Elmstrom, K., and Kennett, J. P., 1985. Late Neogene paleoceanographic evolution of Site 590: southwest Pacific. In Kennett, J. P., von der Borch, C. C., et al., Init. Repts. DSDP, 90, Pt. 2: Washington (U.S. Govt. Printing Office), 1361-1383.

Graf, G., 1989. Benthic-pelagic coupling in a deep-sea community. $\mathrm{Na}$ ture, 341:437-439.

Harman, R., 1964. Distribution of foraminifera in the Santa Barbara Basin, California. Micropaleontology, 10:81-96.

Hemleben, C., Anderson, O., and Spindler, M., 1989. Modern Planktonic Foraminifera: Berlin-Heidelberg-New York (Springer-Verlag).

Hendrix, W., 1958. foraminifer shell form, a key to sedimentary environment. J. Paleontol., 32:649-659.

Jahnke, R., Heggio, D., Emerson, S., and Grundmaris, V., 1982. Pore water of the central Pacific Ocean: nutrient results. Earth Planet. Sci. Lett., 61:233-256.

Kroon, D., and Ganssen, G., 1988. Northern Indian Ocean upwelling cells and the stable isotopic composition of living planktonic foraminifera. In Brummer, G., and Kroon, D. (Eds.), Planktonic Foraminifera as Tracers of Ocean-Climate History: Amsterdam (Amsterdam Univ. Press), 298-316.

Leinen, M., 1979. Biogenic silica accumulation in the central equatorial Pacific and its implications for Cenozoic paleoceanography: summary. Geol. Soc. Am. Bull., 90:801-803.

Leutenegger, S., and Hansen, H., 1979. Ultrastructural and radiotracer studies of pore function in foraminifera. Mar. Biol., 54:11-16.

Lutze, G., and Coulbourn, W., 1984. Recent benthic foraminifera from the continental margin of northwest Africa: community structure and distribution patterns. Mar. Micropaleontol., 8:361-401.

McCorkle, D., Emerson, E., and Quay, P., 1985. Stable carbon isotopes in marine porewaters. Earth Planet. Sci. Lett., 74:13-26.

Miller, K., and Lohmann, G., 1982. Environmental distribution of Recent benthic foraminifera on the northeast United States continental slope. Geol. Soc. Am. Bull., 93:200-206.

Molina-Cruz, A., and Price, P., 1977. Distributions of opal on the ocean floor of the subtropical southeastern Pacific. Geology, 5:8184.

Peterson, L. C., 1984. Recent abyssal benthic foraminiferal biofacies of the eastern equatorial Indian Ocean. Mar. Micropaleontol., 8:479519 . 
Phleger, F., and Soutar, A., 1973. Production of benthic foraminifera in three east Pacific oxygen minima. Micropaleontology, 19:110-115.

Poag, W., 1981. Ecologic Atlas of Benthic Foraminifera of the Gulf of Mexico: Stroudsberg, PA (Hutchinson Ross).

Poag, W., and Low, D., 1984. Environmental trends among Neogene benthic foraminifers at Deep Sea Drilling Project Site 548, Irish continental margin. In de Graciansky, P. C., Poag, C. W., et al., Init. Repts. DSDP, 80: Washington (U.S. Govt. Printing Office), 489503.

Pokras, E., and Molfina, B., 1986. Oceanographic control of diatom abundances and species distributions in surface sediments of the tropical and southeast Atlantic. Mar. Micropaleontol., 10:165-188.

Rex, M., 1976. Biological accommodation in the deep-sea benthos: comparative evidence on the importance of predation and productivity. Deep-Sea Res., 23:975-987.

Schuette, G., and Schrader, H., 1981. Diatom taphocoenoses in the coastal upwelling area off southwest Africa. Mar. Micropaleontol., 6:131-155.

Sen Gupta, B., Lee, R., and May, M., 1981. Upwelling and an unusual assemblage of benthic foraminifera on the northern Florida continental slope. J. Paleontol., 55:853-857.

Shackleton, N. J., and Kennett, J. P., 1975. Paleotemperature history of the Cenozoic and the initiation of Antarctic glaciation: oxygen and carbon isotope analyses in DSDP Sites 277, 279, and 281. In Kennett, J. P., Houtz, R. E., et al., Init. Repts. DSDP, 29: Washington (U.S. Govt. Printing Office), 743-755.

Shackleton, N. J., Hall, M., and Boersma, A., 1984. Oxygen and carbon isotope data from Leg 74 foraminifers. In Moore, T. C., Jr., Ra- binowitz, P. D., et al., Init. Repts. DSDP, 74: Washington (U.S. Govt. Printing Office), 599-612.

Tjalsma, L., and Lohmann, G., 1983. Paleocene-Eocene bathyal and abyssal benthic foraminifera from the Atlantic Ocean. Micropaleontol., Spec. Publ., 4:1-90.

von der Borch, C. C., Sclater, J. G., et al., 1974. Init. Repts. DSDP, 22: Washington (U.S. Govt. Printing Office).

Whitmarsh, R. B., Weser, O. E., Ross, D. A., et al., 1974. Init. Repts. DSDP, 23: Washington (U.S. Govt. Printing Office).

Woodruff, F., 1985. Changes in Miocene deep-sea benthic foraminifera distribution in the Pacific Ocean: relationship to paleoceanography. In Kennett, J. P. (Ed.), The Miocene Ocean. Mem. Geol. Soc. Am., 163:131-176.

Woodruff, F., and Savin, S., 1989. Miocene deepwater oceanography. Paleoceanography, 4:87-140.

Wyrtki, K., 1973. Physical oceanography of the Indian Ocean. In Zeitschel, B. and Gerlach, S. A. (Eds.), The Biology of the Indian Ocean: Berlin-Heidelberg-New York (Springer-Verlag), 18-36.

Zahn, R., Winn, K., and Sarnthein, M., 1986. Benthic foraminiferal $\delta^{13} \mathrm{C}$ and accumulation rates of organic carbon: Uvigerina peregrina group and Cibicidoides wuellerstorfi. Paleoceanography, 1:27-42.

Date of initial receipt: 1 June 1989

Date of acceptance: 15 January 1990

Ms 115B-162 


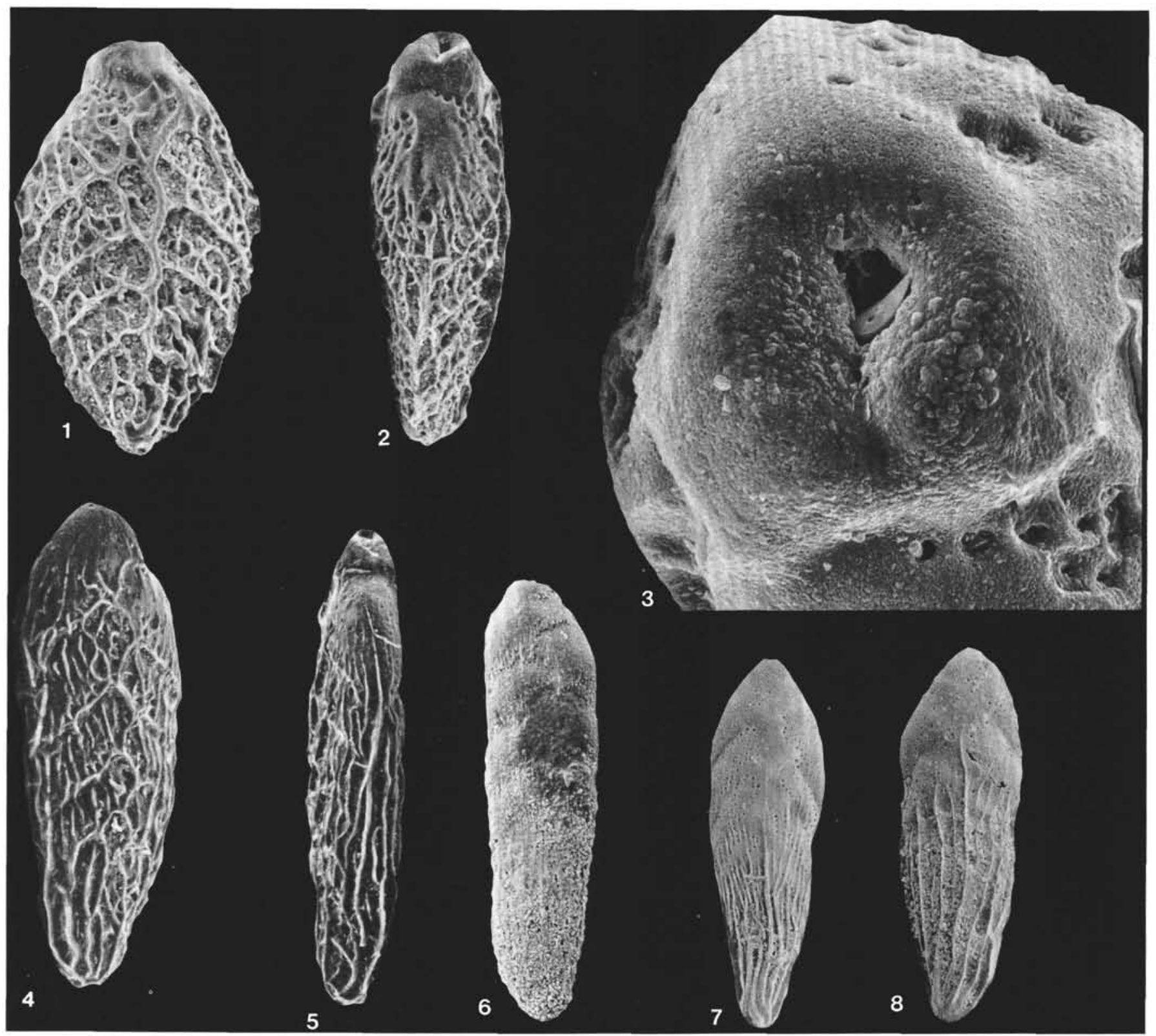

Plate 1. Typical bolivinids of Group 2, characterized by lenticular cross-sections, a sort of fish-bone pattern in the median and sutural area (somewhat visible on 7), medium to large pores, and surface ornamentation in the form of costulae, costae, keels, or reticulations. 1-5. Bolivina cancellata Bermudez; Sample 115-714B-5H-3, $120 \mathrm{~cm}$. (1) Front view, $\times 200$. (2) Side view, $\times 200$. (3) Detail of rounded aperture when last chamber is added uniserially, $\times 400$; test is lanceolate and moderately inflated, pores are large. (4) Microspheric generation, front view, $\times 200$. (5) Side view, $\times 200$. 6, 7, 8. Bolivina pusilla Schwager, Sample 115-714B-5H-6, $120 \mathrm{~cm}$. (6) $\times 200$. (7) Sample 115-707A-15X-CC, $\times 100$. (8) Sample 115-714B$8 \mathrm{H}-6,120 \mathrm{~cm}, \times 110$. 


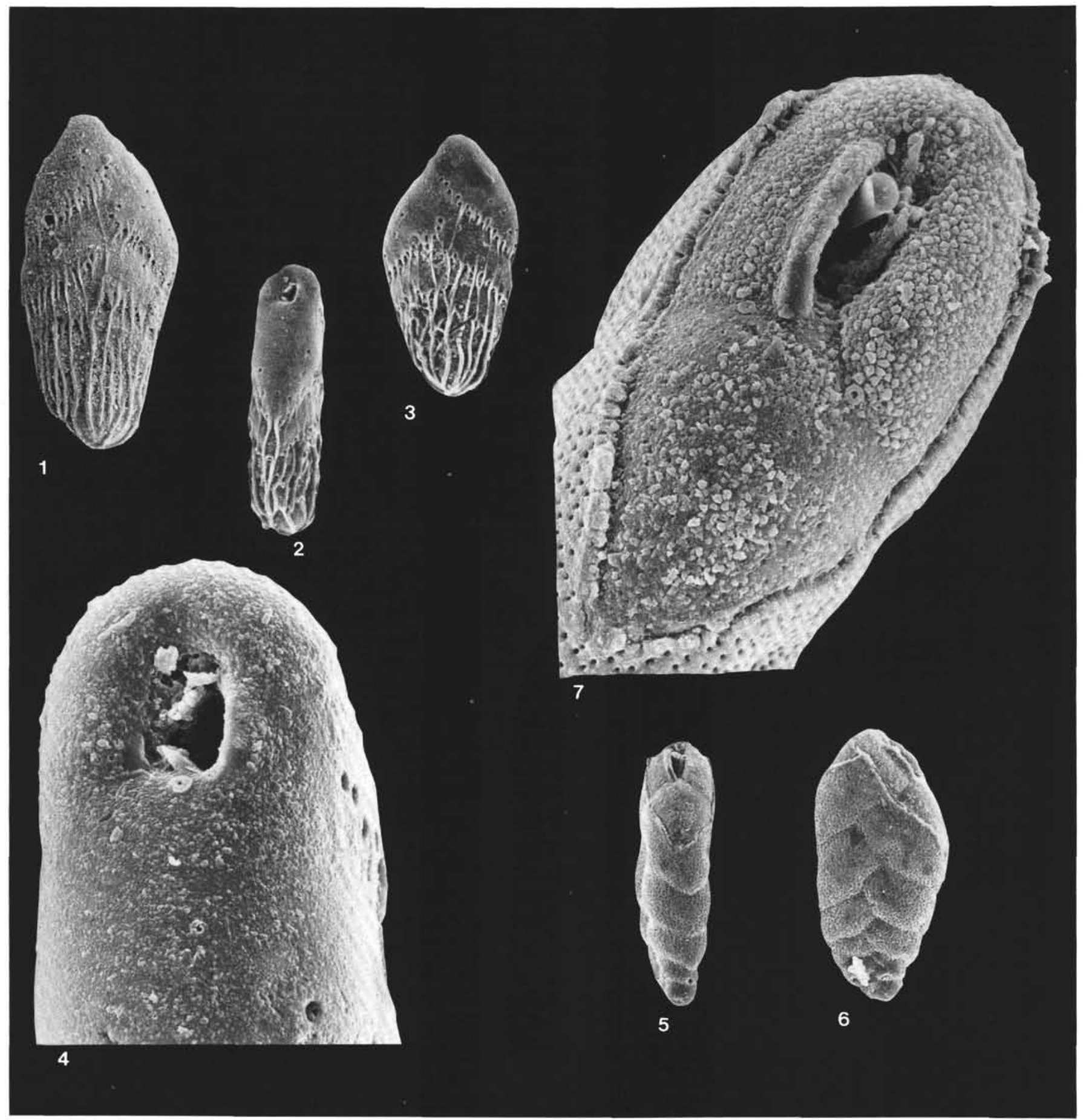

Plate 2. Typical bolivinids of Group 3 characterized by lenticular cross-sections, medium to coarse pores, and chambers that overlap in the median line of the test. 1. Bolivina optima Cushman; Sample 115-714B-5H-6, $120 \mathrm{~cm}, \times 200$. 2, 3, 4. Bolivina aenariensis Cushman; Sample 115-714B$8 \mathrm{H}-4,30 \mathrm{~cm}$. (2) Side view, $\times 200$. (3) Front view, $\times 200$. (4) Enlargement of aperture, $\times 400$. Pores are larger and largely restricted to the sutural area. 5, 6, 7. Bolivina pukeuriensis Finlay; Sample 115-714B-8H-4, $30 \mathrm{~cm}$. Although the chambers overlap, they are moderately inflated and so sutures are curved. Note the small pores randomly distributed over the chamber surfaces. (5) Side view, $\times 200$. (6) Front view, $\times 200$. (7) Enlargement of aperture showing a columnar toothplate projecting from under the apertural rim; also shows secondary pore enlargement that occurs in the outer carbonate layer. Pores in the inner layer are much smaller. For this reason, pore size must be estimated from the inside of the test $(\times 400$ ). 


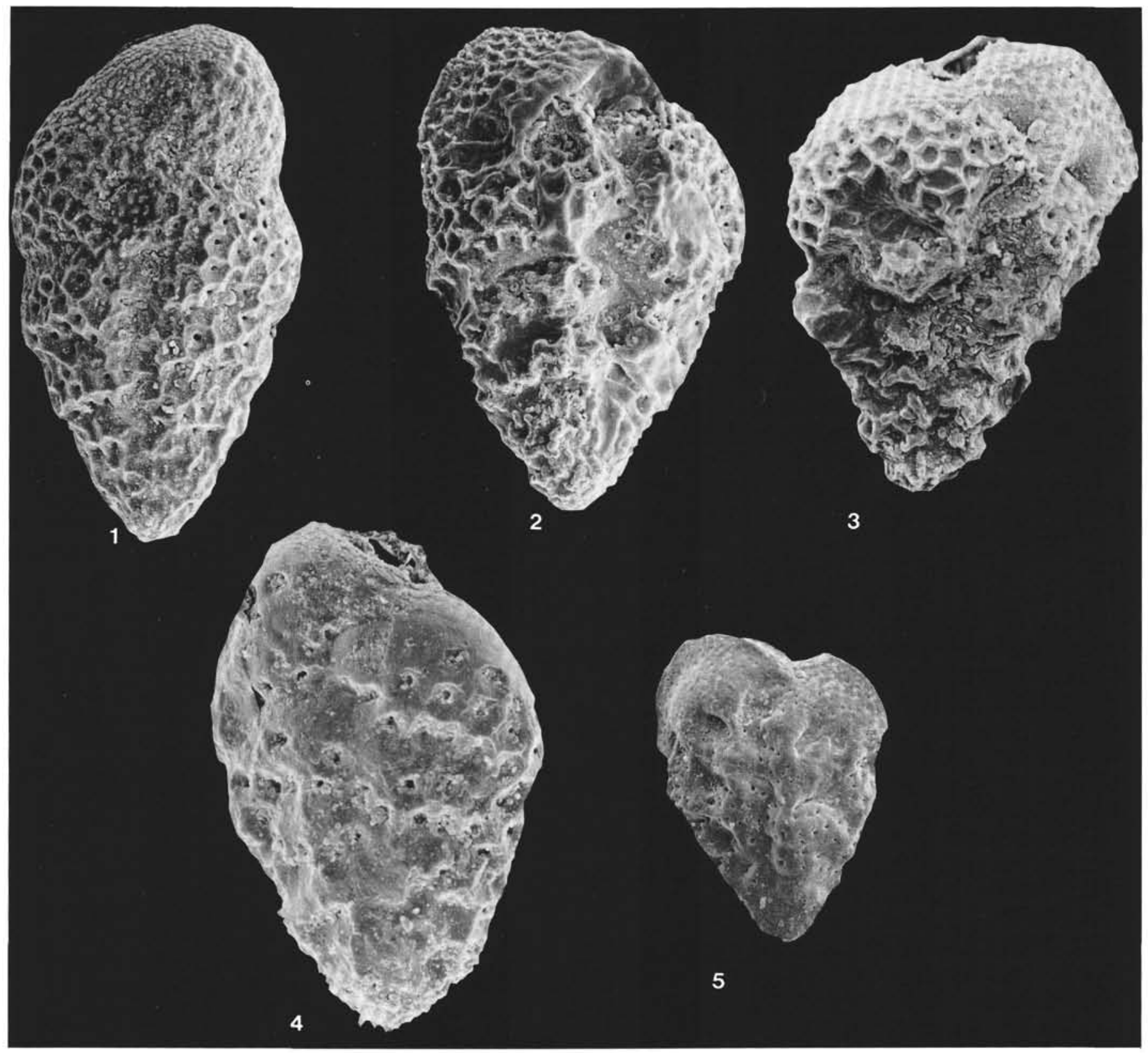

Plate 3. Typical bolivinids of Group 4 characterized by large pores often surrounded by ridges, short tests subrhomboid to oblate in cross-section, and folding of the chambers into crenulations that may align into folds running nearly the length of the test. 1, 2, 3. Bolivina pseudoplicata HeronAllen and Earland; Sample 115-714B-5H-6, $120 \mathrm{~cm}$, all $\times 400$. 4. Bolivina $\mathrm{cf}$. B. alvarezi Sellier de Curieux; Sample 115-716A-13H-CC, $\times 400$. 5. Bolivina peregrina Schwager; Sample 115-714B-5H-6, $120 \mathrm{~cm}, \times 100$. 


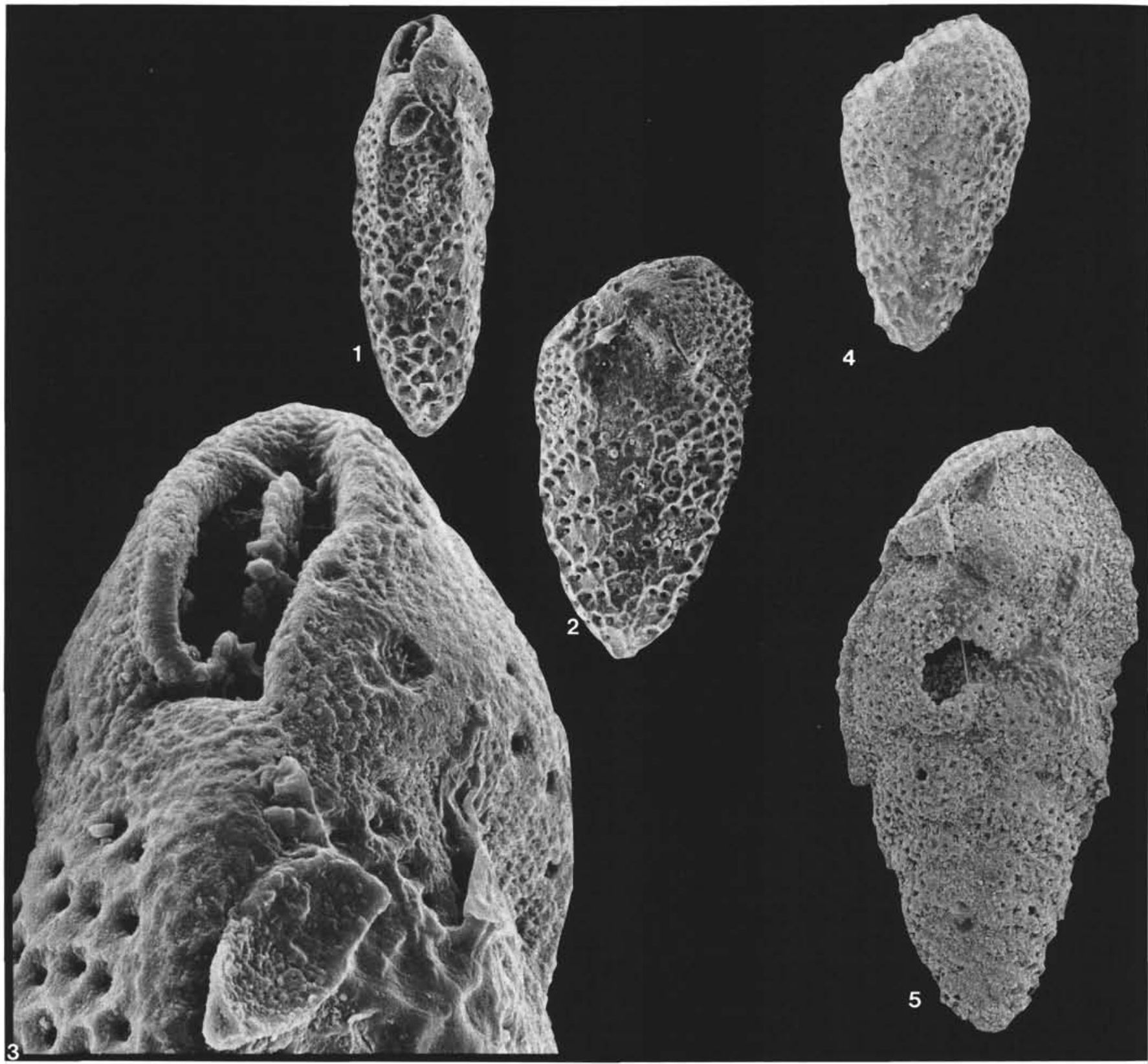

Plate 4. Typical bolivinids of Group 5 characterized by medium to large pores, lenticular to thin cross-sections, moderately straight sutures, and medium to large size. 1, 2,3. Bolivina pulchra Rhumbler. Because there is no real description or holotype, these forms are only temporarily placed in this species; Sample 115-714B-5H-3, $120 \mathrm{~cm}$. (1) Side view, $\times 200$. (2) Front view, $\times 200$. (3) Enlargement of aperture showing platelike tooth plate emerging under apertural rim, $\times 400$. 4. Bolivina $\mathrm{cf}$. B. pulchra Schwager; Sample 115-714A-23X-CC, $\times 200$; Oligocene-age analog of the Neogene species, B. pulchra. 5. Bolivina pseudobeyrichi Cushman; Sample 115-716A-13H-CC, $\times 200$. 